\title{
"WE LIVE'S IN A FREE HOUSE SUCH AS IT IS": CLASS AND THE CREATION OF MODERN CIVIL RIGHTS
}

\author{
RISA L. GOLUBOFF
}

INTRODUCTION

The shift during the 1940s from American public concern with class to concern with race has become a commonplace in American historiography. Alan Brinkley has written that World War II

was a significant moment in the shift of American liberalism from a preoccupation with "reform" (with a set of essentially class-based issues centered around confronting the problem of monopoly and economic disorder) and toward a preoccupation with "rights" (a commitment to the liberties and entitlements of individuals and thus to the liberation of oppressed people and groups).'

Gary Gerstle has come to a similar conclusion, observing a "seismic" shift in which liberals "committed [themselves] to civil rights ... [and] concerns with class division and the ill effects of capitalist civilization ... lost their primacy" on "the liberal agenda." Brinkley and Gerstle seem to assume at least a historical and perhaps even a natural correlation between government regulation and class on the one hand, and between individual rights claims and race on the other. Even as they acknowledge that class issues "did not disappear from the

* Letter from Robert Hammond, Recording Secretary, Wando, S.C., to NAACP (Apr. 26, 1947) (on file with NAACP Papers, Library of Congress, Wash., D.C. (NAACP Papers), Part 13, Series C, Reel 2).

${ }^{\dagger}$ Research Associate Professor, University of Virginia School of Law; B.A., Harvard University; M.A., Princeton University; J.D., Yale Law School. The author would like to thank Ariela Dubler, Myriam Gilles, Dirk Hartog, Dan Rodgers, and Rich Schragger. All sources from the NAACP Papers are on file with the author.

1 ALAN BRINKLEY, THE END OF REFORM: NEW DEAL LIBERALISM IN RECESSION AND WAR 170 (First Vintage Books ed. 1996) (1995).

${ }^{2}$ Gary Gerstle, Protean Character of American Liberalism, 99 AM. HIST. REv. 1043, 1070 (1994) [hereinafter Gerstle, Protean Character]; see also GARY GERSTLE, AMERICAN GRUCIBLE: RACE AND NATION IN THE TWENTIETH CentURY 240 (2001) [hereinafter GERSTLE, RACE AND NATION] (observing that, during the Cold War, "the civic and racial traditions on which the nation's vigor had long depended were undergoing complex change"). 
liberal agenda," ${ }^{3}$ they nonetheless describe them as separate from, and contrasted with, the modern thing called "civil rights" that was created in the 1940s. ${ }^{4}$

But there is neither a natural correlation between race and rights nor a historical one. While I agree with Brinkley and Gerstle that racial concerns became more prominent in the 1940s than they had been before; I do not agree that the concept of "civil rights" encompassed race to the exclusion of class. In fact, as I have argued elsewhere, there was no settled category called civil rights in the 1940s; rather, there were many lay people, lawyers, and institutions searching for "rights" to formulate and constitutionalize. ${ }^{5}$ The federal government, for example, was struggling to find a place in rights creation and enforcement. ${ }^{6}$ And the NAACP's new Legal Defense and Education Fund (Inc. Fund) ${ }^{7}$ was only beginning to contemplate the attack on Plessy v. Ferguson ${ }^{8}$ that would eventually lead to Brown v. Board of Education. ${ }^{9}$ Frameworks, strategies, and outcomes remained uncertain.

The individual rights assertions one finds trapped in the NAACP's voluminous archives-particularly in the labor-related claims of southern agricultural workers-show how varied conceptions of civil rights were during the 1940s. More specifically, they show voices actively pushing the Inc. Fund toward economics and class issues. Dur-

${ }^{3}$ Gerstle, Protean Character, supra note 2, at 1070.

${ }^{4}$ See also Peter J. Kellogg, Civil Rights Consciousness in the 1940s, 42 Historian 18, 36 (1979) (arguing that, after World War II, public and political attention became attuned to three main considerations, namely (1) moral qualms involving democratic principles violated by racism, (2) a fear of violence, and (3) political competition for a growing African American vote, all of which "seemed to come together in 1948 to make civil rights appear to be the main issue of American domestic politics").

${ }^{5}$ Risa L. Goluboff, The Thirteenth Amendment and the Lost Origins of Civil Rights, 50 DUKE L.J. 1609, 1611-12, 1629-34 (2001).

${ }^{6}$ See id. at 1618 (discussing the Department of Justice Civil Rights Section's original focus on labor issues and subsequent shift to "attack[ing] racial inequalities and harms").

${ }^{7}$ In 1939, the NAACP separated out its legal activities in to the NAACP Legal Defense and Education Fund, commonly called the Inc. Fund, although the relationship between the Inc. Fund and the NAACP remained considerably intertwined until 1956. See MARK V. TUSHNET, MAKING Civil, RightS LAW 27, 310 (1994) (explaining the tax reasons for the initial creation of the separate Inc. Fund in name in 1939, and its separation in practice in 1956). I use either "Inc. Fund" or "legal department" when referring exclusively to legal actions and decisions, and "NAACP" when referring to the organization as a whole.

${ }^{8} 163$ U.S. 537 (1896).

347 U.S. 483 (1954). 
ing this decade of confusion and experimentation, then, the assertion of African American rights did not always take the now familiar form of equal-protection-based antidiscrimination claims divorced from class. What did take that form were the rights claims that the most vocal and successful black lawyers-those in the Inc. Fund-chose to validate, pursue, and make doctrinally foundational. The NAACP lawyers marginalized, cabined, and outright repudiated class issues through the complaints they pursued and those they ignored. By the 1950 s, when the antisegregation strategy that eventually led to Brown coalesced, they had succeeded in writing class out of their story.

They succeeded in writing it out of our story as well. The correlation between the Inc. Fund's economically neutralized agenda and a historiography that sees rights in the 1940 s as noneconomic is no coincidence. Historians are wrong about the essential nature of individual rights because they have ignored the class-bound aspects of many rights claims of the period. They have ignored these claims because they have largely taken their history and their understanding about civil rights from the NAACP's understanding and agenda. Equating the kinds of rights the Inc. Fund sought to protect with the complete set of rights African Americans sought to assert has thus led historians astray. ${ }^{10}$ Whether individual rights in the 1940 s can accurately be said to include class as well as race concerns depends in large part on whose rights one examines.

The project of this Article is to recapture the nascent rights claims of southern agricultural workers largely overlooked by both the Inc. Fund and the historiography. Recapturing these claims offers two lessons. First, their very existence at the intersection of race and class undermines the historiography's description of a temporal shift from one to the other. Similarly, these claims disrupt the historiography's correlatives of economic regulation and race-based individual rights. The complaints of African American southern agricultural workers fracture the simple dichotomies-both temporal and conceptualthat we have come to accept." The second lesson stems not from the

${ }^{10}$ Recently, historians like Tomiko Brown-Nagin have begun to explore the complicated relationships between the national office of the NAACP, the NAACP branches, and particular African American communities involved in civil rights struggles. Tomiko Brown-Nagin, Race as Identity Caricature: A Local Legal History Lesson in the Salience of Intraracial Conflict, 151 U. PA. L. REV. 1913 (2003); see also Derrick A. Bell, Jr,, Serving Two Masters: Integration Ideals and Client Interests in School Desegregation Litigation, 85 YALE L.J. 470, 515-16 (1976) ("[T] he suggestions in this article . . . are controversial only to the extent they suggest that some civil rights lawyers . . . are making decisions, setting priorities, and undertaking responsibilities that should be determined by their clients and shaped by their community."). 
t we have come to accept. ${ }^{11}$ The second lesson stems not from the existence of these claims but from their disappearance. While the cases the Inc. Fund chose to pursue, as well as the many doctrinal, political, and institutional reasons for its decisions, extend beyond the scope of this Article, the simple fact that choices were made forms the core of my present argument. ${ }^{12}$ Until now, it has been impossible to see these critical choices because historians have ignored the potential cases the Inc. Fund left behind. Examining those cases illustrates the openness that characterized the creation of civil rights in the 1940s.

\section{COMPLAINTS FROM THE RACIALIZED POLITICAL ECONOMY OF THE AGRICULTURAL SOUTH}

Throughout the 1940s, letters from African American southern agricultural workers streamed steadily into the NAACP's national office. Some came directly from the workers themselves, others from branches that had gotten involved in individual cases, and still others from outside organizations and individuals on behalf of the workers. While it is difficult to construct a wholesale civil rights doctrine out of the issues raised in these complaints (and that is not my project), it is easy to see that the issues the agricultural workers raised, and the kind of legal doctrines those issues might have inspired, looked very different from the issues the Inc. Fund pursued and the doctrine it created. In particular, the stories that follow show the abundance of individual assertions of rights far beyond the Inc. Fund's univalent definition of "injustice because of race or color." ${ }^{13}$

The complaints I discuss below all arose within the particular racialized political economy of the agricultural South. With the possible exception of a few successful African Americans who managed to acquire their own land, the position of black agricultural workers was

"I do not suggest that African American southem agricultural workers are the only group whose complaints combined economic and racial issues, but the combination is especially visible in their complaints.

${ }^{12}$ I explore the reasons for the Inc. Fund's exclusion of agricultural cases from its litigation agenda in the 1940s in my dissertation, The Work of Civil Rights in the 1940s: The Department of Justice, the NAACP, and African American Agricultural Labor (forthcoming 2003) (unpublished Ph.D. Dissertation, Princeton University) (on file with author). While this Article suggests the doctrinal reasons for the Inc. Fund's decisions-based in the pursuit of univalent race claims rather than multivalent race and class claims-the dissertation argues that the NAACP's changing political and institutional commitments during the 1940 s converged with the development of that doctrinal goal.

${ }^{13}$ Procedure for Legal Defense and Voting Cases (June 1939) (on file with NAACP Papers, Part 15, Series A, Reel l). 
generally one of extreme dependency, considerable isolation, and actual or virtual immobility. Wage workers, tied to no particular parcel of land, were simultaneously more mobile and more vulnerable to white control than other farmworkers. They also usually exercised the least economic power and endured the poorest living conditions. As tenant farmers, and especially as sharecroppers, ${ }^{14}$ many African Americans lived on the land of a (usually white) landowner, whom they paid either with money presumably made from the crop (as was the case for cash tenants), or with a share of the crop (as for other types of tenants and sharecroppers). Because both types of renters (but especially sharecroppers) rarely had the cash necessary to buy the seeds, fertilizer, storage space, or tools they would need for the coming season, they often had to rely on their landlords (or other local white landowners and merchants) to "furnish" such things, usually at an exorbitant rate to be repaid when the crop was harvested. Sharecroppers did so more often (and for more items) than tenants, and, more in debt to their landlords, they found themselves subject to greater supervision by them. ${ }^{16}$ Black farmworkers of both the renting and the wage-earning type thus largely lived within a closed economic universe where what money they had was spent in plantation commissaries or in stores that took advantage of their lack of mobility and choice. ${ }^{17}$

\footnotetext{
${ }^{14}$ "Cropper farming is a Negro institution," wrote Arthur Raper in 1936. ARTHUR Franklin Raper, Preface to Peasantry: A Tale of Two Black Belt Counties 14849 (1936).

${ }_{15}$ "Furnish" was the term used for the credit system by which the tenant or sharecropper borrowed food, clothing, and supplies against the following year's crops. See, e.g., Danid Eugene Conrad, The Forgotten Farmers: The StOry of ShareCROPPERS IN THE NEW DEAL. 11 (1965) ("From the time the season began until the crop was made, the tenant was likely to be completely dependent on the commissary for 'furnish,' or food and clothing."); DONALD H. GRUBBS, CRY FROM THE COTTON: The Southern Tenant Farmers' Union AND the New DEAL 9 (1971) ("The sharecropper's previous harvest earnings were supposed to last him until March, when he could begin receiving supplies on credit, 'furnish.' The 'furnish' system gave the worker another master....").

${ }^{16}$ Frank J. Welch describes these terms, and the system as a whole, in some detail in The Plantation Land Tenure System in Mississippi (1943).

${ }^{17}$ Historians have written extensively on the contours of this racialized political economy. They have long debated the extent of African American mobility following the Civil War and into the twentieth century. For the argument that the combination of law and custom succeeded in curtailing almost all African American movement, see Pete Daniel, The Shadow of Slavery: Peonage in the South, 1901-1969 ix (1972); Gerald David Jaynes, Branches Without RoOts: Genesis of the Black Working Class in the AMERICAN SOUTH, 1862-1882, at 254 (1986); JAY R. MANDLE, NOT SLAVE, Not FreE: The African AMERICAN ECONOMIC EXPERIEnCE Since THE CIVIL WAR 33
} 
State and local laws still on the books in the 1940s reinforced these conditions of limited African American mobility. The roots of many such laws went all the way back to the post-Civil War Black Codes, though their overtly racial character had long been eliminated by $1940 .^{18}$ Hitchhiking laws, for example, curtailed mobility by eliminating a critical, free mode of transportation. ${ }^{19}$ Emigrant agent licensing laws limited information flows by requiring labor recruiters to pay often exorbitant amounts for the opportunity to recruit labor in southern states. ${ }^{20}$ Some states, like Virginia, required agents soliciting on behalf of employers outside the state to pay $\$ 5000$ per year for each county or city in which they operated. ${ }^{23}$ Alabama went even further, requiring the same amount not only for counties in which an agent operated, but those through which he transported workers. ${ }^{22}$ Similarly, "anti-enticement" laws, which southern states also kept on

(1992); Daniel A. Novak, The WheEl of SERVITUde: Black Forced Labor After SlaVERY 2 (1978); Pete Daniel, The Metamorphosis of Slavery, 1865-1900, 66 J. AM. HIST. 88, 89-90 (1979); Jonathan M. Wiener, Class Structure and Economic Development in the American South, 1865-1955, 84 AM. HIST. REV. 970, 970 (1979). For the perspective of those who find that, despite the law, African Americans moved freely throughout the South, see RoBERT Higgs, COMPETTTION AND COERCION: BLACKS IN THE AMERICAN ECONOMY, 1865-1914, at 26-27 (1977); Stephen J. DeCanio, Accumulation and Discrimination in the Postbellum South, in MARKET INSTITUTIONS AND ECONOMIC PROGRESS IN THE NEW SOUTH, 1865-1900, at 103, 105, 130-31 (Gary M. Walton \& James F. Shepherd eds., 1981); Joseph D. Reid, Jr., White Land, Black Labor and Agricultural Stagnation: The Causes and Effects of Sharecropping in the Postbellum South, in MARKET INSTITUTIONS AND ECONOMIC PROGRESS IN THE NEW SOUTH, 1865-1900, supra, at 45. For integrative views, see ROgER L. RANSOM \& RICHARD SUTCH, ONE KIND OF FREEdom: THE ECONOMIC CONSEQUENCES OF EMANCIPATION 61-64, 193-97 (1977); William Cohen, Negro Involuntary Servitude in the South, 1865-1940: A Preliminary Analysis, 42 J. S. HIST. 31, 31 (1976). My point is less about the extent of mobility than about the ways in which white southerners attempted to restrict it and the fact that African Americans challenged these attempts by seeking help from the NAACP.

${ }^{18}$ NOVAK, supra note 17 , at $1-8$.

${ }^{19}$ E.g., N.C. Gen. STAT. $\$ 2621$ (99e) (1935); ARK. STAT. ANN. \$ 75-630 (1947).

${ }^{20}$ See Novak, supra note 17 , at 39 (describing enticement laws); Jennifer Roback, Southern Labor Law in the fim Crow Era: Exploitative or Competitive?, 51 U. CHI. L. REV. 1161,1169 (1984) (noting licensing fees of up to $\$ 5000$ for each county in which recruiting took place).

${ }^{21}$ VA. CODE ANN. app. $\$ 183$ (Tax Code) (Michie 1942).

${ }^{22}$ ALA. CoDE tit. 51, $\$ 513$ (1940); see also Fla. STAT. $\$ 205.39$ (1941) (\$2000 for the state); N.C. GEN. STAT. $\$ 7880(85)$ (1935) ( $\$ 500$ per county); S.C. CODE ANN. $\$$ 1378 (1942) (\$2000 per county). See generally David E. BernsteIn, ONLy ONE PlaCE OF REDRESS: AFRICAN AMERICANS, LABOR REgulations, AND THE COURTS FROM RECONSTRUCTION TO THE NEW DEAL 12 (2001); Roback, supra note 20, at 1169 (“The primary economic effect of the emigrant agent laws was to increase the cost to black laborers of obtaining information about job opportunities outside their local market area."). 
the books into the 1940s, made it a crime for an employer to entice a laborer away from his or her current employment. ${ }^{23}$

Political repression accompanied economic exploitation. Most black southerners, especially rural southerners, did not vote in the 1940s South, let alone hold public office. And, despite favorable longstanding constitutional precedent, ${ }^{24}$ they did not sit on juries. They did not serve as judges or police officers, and the latter often perpetrated violence against African Americans rather than protected them from it. Political participation was so inaccessible to African Americans that many did not even read about elections, voting, or democracy in textbooks created specifically for black schoolchildren that were legislatively mandated to exclude such topics. ${ }^{2.5}$ Moreover, the boards and committees that implemented and administered the various New Deal programs in agriculture, as well as wartime draft, wage, and price boards, were dominated by whites with economic power over black farmworkers. ${ }^{26}$ At every level and branch of governance, black agricultural workers were unrepresented. The virtual inaccessibility of governmental redress, whether by politics or law, regarding property theft or personal violence, multiplied the pervasiveness of economic dependence. ${ }^{27}$

29 Ala. CODE tit. 26, \$332 (1940); ARK. STAT. ANN. \$ 81-210 (1947); FLA. STAT. \$ 448.02 (1941); GA. CODE ANN. $\$ \$ 66-9904$ to -9905 (1937); N.C. GEN. STAT. $\$ \$ 4469$, 4470 (1935); S.C. CoDE ANN. \$ 7030-10 (1942); TENn. CodE ANN. \$ 8559 (Michie 1938). See generally BERNSTEIN, supra note 22, at 10.

${ }^{24}$ See Strauder v. West Virginia, 100 U.S. 303, 310 (1879) (finding a West Virginia statute banning African Americans from juries violative of the Equal Protection Clause of the Fourteenth Amendment).

${ }^{25}$ TEXTBOOKS IN MISSISSIPPI, OPPORTUNITY, XVIII, at 99 (Apr. 1940).

${ }^{26}$ See Harvard SitKoff, A New DEAL for Blacks: THE EMERGence OF Civil RIGHTS AS A NATIONAL ISSUE 53 (1978) ("Not a single Negro served on an [Agricultural Adjustment Administration] county committee throughout the South."); Pete Daniel, Going Among Strangers: Southern Reactions to World War II, 77 J. AM. HIST. 886, 891 (1990) (explaining that draft boards in Mississippi were "'made up of planters" and that "[d]eferred workers ... "do not feel free to leave the farm of the operator who requested their deferment'" (quoting a 1943 Bureau of Agricultural Economics study)).

See CoNRAD, supra note 15, at 205-06 (concluding that government agency favoritism toward landowners exacerbated the plight of sharecroppers in the South); GRUBBS, supra note 15, at 212-13 (explaining how landlords could manipulate the law to swindle tenants out of their money); HAROLD D. WOODMAN, NEW SOUTH, NEW LAW: The Legal Foundations of Credit and Labor Relations in the Postbellum AGRICULTURAL SOUTH 111 (1995) ("[T] he evolution of the legal changes in the South after the Civil War seems clearly to be the result of a resurgent landowning class being able to impose its will on helpless freedmen and a merchant class able to impose its will on small landowners and tenants."). 
As a consequence, opportunities for planter control and intimidation were ubiquitous and frequently exploited. But the workers did not accept the consequences silently. They complained, to the NAACP among others. I have divided the complaints I found in the NAACP Papers into three categories generally involving rights to property and mobility. The first set includes a variety of complaints about white landowners who managed either to acquire the property of African American farmers or to prevent African Americans from acquiring property elsewhere, through force, intimidation, and discrimination. ${ }^{28}$ Often these incidents originated in landlord resentment at and retaliation against those African Americans who had managed to secure some amount of independence or wealth. The second set, which is comprised of a single case with widespread origins and effects, concerns wages for cotton picking. ${ }^{29}$ Wage ceilings imposed during the war acted as a restraint on property-most specifically wages-and as a restraint on mobility indirectly. The third, and most prominent and self-defining, set of southern agricultural complaints the NAACP saw in the 1940s involved direct restraints on personal mobility, in the form of involuntary servitude and peonage. ${ }^{30}$ After discussing the complaints in each category and the NAACP's responses to those complaints, I conclude with a brief discussion of the fundamental difference between these multivalent race/class rights assertions and the univalent agenda the Inc. Fund ultimately pursued. $^{81}$

${ }^{28}$ See infra Part II (describing how landlords bound African American renters to the land on which they worked, thus limiting their opportunities for independence).

${ }^{29}$ See infra Part III (arguing that wage ceilings restrained the freedom of movement of laborers, to the benefit of their employers and landlords).

${ }^{30}$ See infra Part IV (considering white employers' desire to obtain costless labor through the elimination of worker mobility). It is important to note that these three categories do not, of course, exhaust the kinds of issues that arose in the agricultural South. I have omitted two significant topics in particular-the question of mechanization and the complicated approach the NAACP took to the importation of foreign (especially Mexican) agricultural labor into the United States-as they involve not only the issues African Americans faced in southern agriculture but also the movement of African Americans out of agricultural work altogether.

${ }^{31}$ See infra Part V (outlining the Inc. Fund's exclusive definition of race discrimination and the major types of cases in which the Inc. Fund became involved). 


\section{II. "I Have a CaSe Her I HaVe BeEn Robe OUT OF My Livin AND RIGHTS": ${ }^{32}$ INDEPENDENCE AND THE VULNERABILITY OF BLACK SOUTHERN PROPERTY}

African American tenant farmers and sharecroppers could rarely afford the start-up costs of planting a crop. They often borrowed the necessities from their landlords, and usually continued borrowing throughout the year. They were often so far into debt by harvest time that their share of the crop could not even cover the prior season's debt, let alone provide enough capital to forgo debt for the following season. The law-in the form of the crop lien laws most states continued to maintain into the 1940s-helped ensure that black agriculturalists would fail to see any profit from their crops. Crop lien laws gave priority to landlords, and many gave second priority to others, like merchants, who also lent supplies to tenants. ${ }^{33}$ These laws meant that the loss from crops that failed to make a profit fell disproportionately on tenants. Sharecroppers, meanwhile, often had no legal rights to the crops at all. ${ }^{34}$ By keeping prices for supplies high and farmworkers isolated from other options, landlords yoked African American renters to the land-and to harvesting the landlords' crops at minimal cost to the landlords." Independence, whether gained through frugality, luck, wage work in winter, or government economic programs, broke the yoke of debt and threatened the economic dominance of the landlords.

When black farmworkers managed to gain some capital, they sought what independence they could afford, which was usually lim-

${ }^{32}$ Letter from Charley Bright to Walter White (Jan. 20, 1945) (on file with NAACP Papers, Part 13, Series C, Reel 2) [hereinafter Letter from Charley Bright].

E.g., FlA. STAT. $\$ \$ 83.10,85.22$ (1941); GA. CODE ANN. $\$ \$ 61-201$ to -203 and annotations (1937); see also GA. CODE ANN. $\$ \$ 67-110$ to -1105 (1937). South Carolina, North Carolina, Texas, and Mississippi gave first priority to landlords and second to tenants. S.C. CODE ANN. $\$ 8773$ (Law. Co-op. 1942); N.C. GEN. STAT. \$ 2355 (1935); TEX. LANDLORD \& TENANT CODE ANN. $\$ 5222$ (Vernon 1947); Miss. CODE ANN. $\$ 336$ (1942).

${ }^{34}$ Pete Daniel, The Legal Basis of Agrarian Capitalism: The South Since 1933, in RACE AND Class IN THE AmERICAN South SINCE 1890, at 79-102 (Melvyn Stokes \& Rich Halpern eds., 1994).

${ }^{35}$ See JOHN DOLlard, CASTE AND Class IN A SOUTHERn TOWN 108-33 (1937) (describing how the relationship between the tenant farmer and the planter bears on the issue of economic gain by the white middle class); GUNNAR MYRDAL, AN AMERICAN DILEMma: The Negro Problem AND MODERN DEMOCRACY 235-50 (1944) (suggesting that the southern plantation and tenure systems contributed to the obstacles African Americans faced to becoming independent farm owners); NOVAK, supra note 17, at 44 62 (stating that peonage plunged the freed slave into a new labor system that degraded his value as a worker and made a mockery of his new economic freedom). 
ited to forgoing landlords' loans and "furnishing" themselves. In response and retaliation, landlords resorted to ever more direct means of expropriating the fruits of the black farmers' labor. ${ }^{36}$ The landlords would simply take what they had been unable to convince (or coerce) the farmworkers to give up contractually-the profit from their crops. The machinations were hardly opaque. One family, whose landlord had ordered to vacate the farm so he could take their crops after they had refused to borrow their share of fertilizer and seed from him, concluded that the landowner "resented their foresight in managing without his credit, and used this method to cheat them out of their entire earnings."

The often successful efforts of these landlords led many black farmers, or those acting on their behalf, to complain to the NAACP in the hopes of retrieving their crops, their money, and their homes. One branch member wrote to the legal office about a widow who complained that her landlord confiscated her crops because her late husband was allegedly indebted to him. The branch suggested that

[t] he case of Mrs. Bass is, we believe a deserving case and is typical of the many cases in North Carolina and the south where the tenant, by devious means is robbed of his work under the pretense of the law. It is our belief that with proper legal defense this case and others could be fought and the tenants would get justice. ${ }^{38}$

Mrs. Bass's case indeed seems typical. Not only did a report of the National Sharecroppers' Fund reinforce the prevalence of such claims, ${ }^{39}$ but the NAACP Papers are filled with letters describing situations quite similar to the one facing Mrs. Bass. Major variations concerned the lengths to which landlords would go in depriving their tenants and retaliating against them. The lucky ones, like Reverend

${ }^{36}$ That small landowners and wage workers are largely absent from these property complaints makes considerable sense. Small landowners, although vulnerable to many forms of discrimination and exploitation, were not dependent on white landowners in the same way tenant farmers and sharecroppers were by virtue of the planters' land ownership. Wage workers' opportunities for economic independence were slim, and they were a threat to plantation owners only through controlling their own labor and mobility, rather than their own property. Thus, wage workers complained far more often about peonage and involuntary servitude.

${ }^{97}$ Letter from Gudrun G. Rom to Walter White (Jan. 10, 1946) (on file with NAACP Papers, Part 13, Series C, Reel 2) [hereinafter Letter from Gudrun G. Rom].

${ }^{38}$ Letter from Chas. G. Irving to Edward R. Dudley (Oct. 29, 1944) (on file with NAACP Papers, Part 13, Series C, Reel 2).

39 Beth Biderman, The Condition of Farm Workers in 1949: Report to the Board of Directors of National Sharecroppers Fund, Inc. 4 (on file with NAACP Papers, Part 13, Series C, Reel 2). 
Valco Harris and Charley Bright, lost only their livelihoods. Harris complained that while "cropping half," the landowner took Harris's crops, refused to show him cotton gin receipts, and refused to pay him for the crops. ${ }^{40} \mathrm{He}$, along with his pregnant wife, their four children, and three other families on the land, wanted to know, "Is it any laws to fource Mr. George Chambers to give me my account and settle with me?"41 Bright similarly failed to see the money from his cotton crop. He wrote, "I have a case her I have been robe out of my Livin and rights."

Lettie Franklin, who wrote concerning "my work and labor," suffered consequences similar to those facing other African Americans who sought to communicate their plight: she ran the risk of losing her home when the farmer on whose land she worked took her crop, refused to furnish her or give her barn space, and wanted to throw her out of her house. ${ }^{4 y}$ Those who did lose their homes, like the perceptive family aware of their landlord's resentment, fled to cities north and south to try to find redress. ${ }^{44}$ Others even lost their lives, as it was not unheard of for a cropper's success and his desire to dispose of his own half of the crop to lead to his death. ${ }^{45}$

To the structural imbalance of landlord and tenant, lender and debtor, politically empowered and politically silenced, many landlords added the absence of a written contract about the division of the crops. A number of complaints identified the lack of a written contract as a problem. Mr. K.B. Brewer of the Charleston, Missouri, branch wrote on behalf of an African American sharecropper named

${ }^{40}$ Letter from Rev. Valco R. Harris to George S. Schulyer (Oct. 9, 1944) (on file with NAACP Papers, Part 13, Series C, Reel 2) [hereinafter Letter from Rev. Harris].

${ }^{41}$ Id.

${ }^{42}$ Letter from Charley Bright, supra note 32.

${ }^{43}$ Letter from Lettie Franklin to "sir" (Oct. 25, 1945) (on file with NAACP Papers, Part 13, Series C, Reel 2).

${ }^{44}$ See Letter from Gudrun G. Rom, supra note 37 (reporting that Mr. Simmons fled from Magnolia, Mississippi, to Chicago with his family out of "fear for his life").

${ }^{45}$ See Letter from J.T. Smith, Greensboro, Fla., to NAACP (Nov. 20, 1946) (on file with NAACP Papers, Part 13, Series C, Reel 2) (describing the "cane syrup murder" committed by a farmer who was successful and debt-free, but who wanted the cropper's share of the cane syrup nonetheless). Indeed, the NAACP tried to publicize the fact that many lynchings stemmed not from rapes or alleged rapes, but from property disputes between white landowners and their black farmworkers. See WALTER WHITE, ROPE \& FAGGOT: A BIOGRAPHY OF JUDGE LYNCH 82 (1929) ("Lynching has always been the means for protection, not of white women, but of profits." (emphasis omitted)); RoBERT L. ZANGRANDO, THE NAACP CRUSADE AGAINST LYNCHING, 1909-1950, at 8-10 (1980) (examining economic and psychological causes of lynchings and mob mentality): 
Boyd, complaining that a local landlord had hired Mexican workers to pick a crop that belonged to Boyd. ${ }^{46}$ Brewer told the NAACP: "No written contract or lease was given the Boyds. The agreement was verbal." ${ }^{47}$ Similarly, the Family Service Bureau of United Charities of Chicago called the NAACP's attention to the fact that one family had only "a verbal agreement" with their landlord. ${ }^{48}$ As Frank Welch, the head of the department of agricultural economics at Mississippi State University, put it in a study of the land tenure system in 1943, "nearly all agreements are oral and informal," one result of which was to make laborers vulnerable to "arbitrary and unfair treatment." The verbal contract was often combined with a refusal to allow sharecroppers to examine a landlord's records, for example, which prevented sharecroppers from effectively contesting alleged, and often fraudulent, debts. ${ }^{50}$

Landlords and rural merchants did not limit their appropriations of black labor and property to the crops themselves. They found ways to deprive black farmers of whatever means the latter used to obtain funds. One significant type of appropriation concerned checks various government agencies sent to agriculturalists through New Deal programs that continued into the 1940s." Sometimes the landowners outright took the checks themselves. ${ }^{52}$ At other times, their tactics were (slightly) more subtle. Lulu White, an active and long-time member of the Houston, Texas, branch of the NAACP informed the national legal department of the problem near Houston: merchants had "been securing from the Post Office[] the Government farm checks and holding them and applying them to the accounts of the

${ }^{46}$ Letter from K.B. Brewer to Thurgood Marshall (Dec. 8, 1948) (on file with NAACP Papers, Part 13, Series C, Reel 2).

${ }^{4} \mathrm{Id}$.

48 Letter from Gudrun C. Rom, supra note 37.

${ }^{49}$ WELCH, supra note 16 , at 37.

${ }^{50}$ Daniel, supra note 34.

"s See, e.g., Letter from Thurgood Marshall to Secretary of Agriculture (Feb. 14, 1940) (on file with NAACP Papers, Part 13, Series A, Reel 1) (describing an incident in which a farm tenant was forced to sign over a government check to his landlord).

${ }^{52}$ See CONRAD, supra note 15 , at 64-68 (illustrating incidents where landlords took money due tenants under New Deal programs); GRUBBS, supra note 15, at 30-61 (finding that sharecroppers were cheated and victimized by landlords under New Deal programs); Paul E. Mertz, New Deal. Policy and Southern Rural Poverty 16-17 (1978) (reporting instances of "sheer fraud" on the part of planters and local authorities, such as landlords' practice of securing federal assistance checks directly "and appl[ying] them to croppers' back debts, an action that was illegal"). 
farmers without their consent." ${ }^{, 53}$ As a result, the farmers were forced to spend their checks at the merchants' stores; the merchants thereby transformed potentially independence-producing government funds into further black dependence and white profit. Tampering with the mail, Lulu White suggested, was a federal offense and she urged the NAACP to pursue redress. ${ }^{54}$

Other property deprivation schemes seemed to originate in the government itself and the power that landlords exercised in the local administration of federal government programs. Thus the national office received numerous complaints about black farmers who were having difficulty obtaining government loans on their crops. ${ }^{55}$ Still other complaints, like one from a group of 118 African American families who were being sued for damaging property they had profitably leased as a cooperative under the Farm Security Administration (FSA), were more idiosyncratic. ${ }^{56}$ For the most part, the Inc. Fund showed little interest in these property complaints. Occasionally, as when the confrontation between planters and farm workers rose to such a level of violence that death ensued, the NAACP would intervene. At that point, the case was no longer multivalent; murder rendered it amenable to more familiar frameworks. Those conflicts that ended in the death of the landlord and the trial of the defendant without proper safeguarding of his rights could lead the Inc. Fund to fight to ensure the defendant received due process during his (or, more rarely, her) criminal proceedings. ${ }^{57}$ And those that ended with the death of the African American could at times fall under the rubric of lynching, a subject about which the NAACP had long crusaded. ${ }^{58}$ Even then, however, the extent of intervention was often limited to in-

${ }^{53}$ Letter from Lulu B. White to Thurgood Marshall (Dec. 4, 1944) (on file with NAACP Papers, Part 13, Series C, Reel 2).

${ }^{54}$ Id.

${ }^{55}$ Letter from Marian Wynn Perry to Hon. Clinton P. Anderson, Secretary of Agriculture (July 2, 1947) (on file with NAACP Papers, Part 13, Series C, Reel 2) [hereinafter Letter from Marian Wynn Perry].

${ }^{56}$ Memorandum from Clarence Mitchell to Thurgood Marshall (June 17, 1947) (on file with NAACP Papers, Part 13, Series C, Reel 2) [hereinafter Memorandum from Mitchell to Marshall].

${ }^{57}$ See The Inc. Fund, Semi-Annual Report of the Legal Department, January 1June 30, 1944 (on file with NAACP Papers, Part 18, Series A, Reel 4) (discussing criminal defense cases from the agricultural South). See generally The Legal Front, Some Highlights of the Past Year, 1940 (on file with NAACP Papers, Part 18, Series A, Reel 4) (surveying criminal defense cases).

${ }^{58}$ See ZANGRANDO, supra note 45, at 17 (discussing the NAACP's longstanding involvement with the problem of lynching). 
vestigation and referral to the proper authorities, as when the NAACP convinced the attorney general of Florida to bring before a grand jury a white landowner who had murdered a black sharecropper.

Such extreme incidents were few and far between, however. In the more mundane cases, at best, the national office would write a letter to the appropriate government official, serving as a conduit between the complainant and the government. Thus, Marian Wynn Perry of the national legal department asked the Secretary of the United States Department of Agriculture about the proper officials to whom complaints about the farm loan program should be directed. ${ }^{60}$ When Secretary of Agriculture Clinton Anderson replied that he thought the farm loan program was being administered without discrimination, and that he was "reasonably sure that the instances ... where loans have not been granted resulted from the failure of the applicants to meet the requirements for eligibility," pursue the case further.

Slightly less proactive were the lawyers' decisions to treat the issues as political rather than legal problems and to forward the complaints to the political staff in the Washington Bureau. Clarence Mitchell, the Washington Bureau's labor secretary, tried to give the case of the successful cooperative farmers to Thurgood Marshall. ${ }^{62}$ Marian Perry passed it back to Mitchell, telling the complainant that Mitchell might be able to help by contacting the FSA directly. ${ }^{63}$ Similarly, the legal office sent the complaint about checks disappearing from rural post offices to Washington to see if the post office could work it out. The Washington Bureau wrote the Postmaster General to bring to his attention "certain difficulties [the Southern Tenant Farmers Union] has

${ }^{59}$ Press Release, Franklin H. Williams, In the Case of Wyart Trueblood (Mar. 10, 1947) (on file with NAACP Papers, Part 13, Series C, Reel 9); Letter from Franklin H. Williams to Attorney General of Florida (Jan. 30, 1947); see also ZANGRANDO, supra note 45, at 28 ("[T] he Association was increasingly dissatisfied with merely responding to mob murders as they occurred. Yet, it felt compelled to react to each new horror, since it still lacked the means to launch any major campaign that might reasonably forestall further lynching.").

${ }^{60}$ Letter from Marian Wynn Perry, supra note 55; see also Memorandum from Julia E. Baxter to Clarence Marshall (June 11, 1947) (on file with NAACP Papers, Part 13, Series C, Reel 2) (relaying an NAACP member's request “for information on the Federal crop program for 1947").

${ }^{61}$ Letter from Clinton P. Anderson to Marian Wynn Perry (July 15, 1947) (on file with NAACP Papers, Part 13, Series C, Reel 2).

${ }_{62}$ Memorandum from Mitchell to Marshall, supra note 56.

${ }^{63}$ Letter from Marian Wynn Perry to Mrs. Augustus Evans (July 23, 1947) (on file with NAACP Papers, Part 13, Series C, Reel 2). 
encountered in securing the delivery of mail to their members in the South., ${ }^{64}$

Sometimes, as when the national office responded to Mrs. Texanne Thornton, complainants were referred to the branches or organizations like the Southern Tenant Farmers Union. ${ }^{65}$ Although the national legal department showed some interest in a case where the widow of a farmworker was denied his share of the crop allegedly because he had died in debt to the farmer, it saw branch involvement as an impediment to its own. ${ }^{66}$ More commonly, those complaining of property rights infringements were told, as Charley Bright was, that " $[\mathrm{t}]$ he matter of your letter is a purely private one and does not come within the rules of the Association."

Those rules, as the legal office stated so often in letters like the one to Bright, allowed the Inc. Fund to take cases under only three circumstances: where there was an injustice because of race or color, where there was a denial of due process, or where there was a possibility of establishing precedent that would benefit African Americans substantially. ${ }^{68}$ Had the Inc. Fund seen the property cases as a systematic process of domination, it may have concluded that they fit some interpretations of these "rules": the cases undeniably contained a racial component, they often involved a literal violation of due process of law, and, considering the apparently widespread nature of agricultural property theft and fraud in the South, they might have led to widely beneficial precedents. The lawyers in the national office, however, did not so interpret their rules. What they meant by racial injustice, as I will discuss below, was discrimination solely on the basis of race; what they meant by precedential value was that it forwarded the

${ }^{64}$ Letter from Leslie S. Perry to Hon. Robert N. Hannegan (June 17, 1946) (on file with NAACP Papers, Part 13, Series C, Reel 2).

${ }^{65}$ See Letter from Clarence Marshall to Mrs. Texanne Thornton (Sept. 6, 1945) (on file with NAACP Papers, Part 13, Series C, Reel 2) (referring a claim to the Cairo branch of the NAACP).

${ }^{66}$ Letter from Edward R. Dudley to E.R. Avant (Nov. 2, 1944) (on file with NAACP Papers, Part 13, Series C, Reel 2); see also id. ("I cannot promise whether we will be able to assume responsibility in this matter since the case originated with our Branch in Raleigh in the first place."). Such deference to the branch rarely characterized the national office's approach in cases, like the boilermakers cases discussed infra at notes 173-175 and accompanying text, in which the national organization took a more acute interest.

${ }^{67}$ Letter from Thurgood Marshall to Charley Bright (Jan. 26, 1945) (on file with NAACP Papers, Part 13, Series C, Reel 2) (hereinafter Letter from Marshall to Bright].

${ }^{68}$ Letter from Thurgood Marshall to John Crawford (July 2, 1942) (on file with NAACP Papers, Part 13, Series C, Reel 3) [Letter from Marshall to Crawford]. 
lawyers' attack on Plessy; and what they meant by denial of due process was the violation of constitutional rights in criminal proceedings. ${ }^{69}$ As a result, they saw cases like Charley Bright's as "purely private." They told people like Lettie Franklin that they "sincerely appreciate the gravity of the situation in which you find yourself and regret that we will be unable to give you any concrete assistance at this time." best advice they could muster in many cases where the NAACP was unable to help was to hire a private lawyer. ${ }^{72}$

\section{The Ceiling "Whipped the SMall Negro OWNer and Tenant to DEATH": ${ }^{73}$ COTTON WAGE CEILINGS AND MOBILITY IN A "FREE" MARKET}

The NAACP evinced somewhat more, though still quite minimal, interest in the issues raised by the United States Department of Agriculture's imposition of wage ceilings on cotton picking right at the end of World War II. While the property cases involved primarily sharecroppers and tenant farmers, the wage ceiling issue not only affected those categories (as both were sometime wage laborers and sometime employers) but also -small landowners a step above and wage laborers a step below. Moreover, in the property cases, the challenge was primarily against private power exercised by individual property owners (backed, of course, by the knowledge that state power would support them if challenged); in the case of wage ceilings, the challenge was to the owners' harnessing of the power of the state to interfere directly with the labor market. Because that interference was aimed at leveling wages and preventing market mobility by cotton workers, the wage ceiling issue concerned both workers' earnings as well as their freedom of movement.

Under the Emergency Price Control Act of 1942, authority to regulate the wages of agricultural workers was delegated to the Direc-

\footnotetext{
69 See infra Part V (discussing the Inc. Fund's interpretation of "injustice because of race").

${ }^{70}$ Letter from Marshall to Bright, supra note 67; see also Letter from Marshall to Crawford, supra note 68 ("Such a case is a purely private matter.").

${ }^{71}$ Letter from Robert L. Carter, Assistant Special Counsel, to Mrs. Lettie Franklin, Mt. Airy, N.C. (Oct. 30, 1945) (on file with NAACP Papers, Part 13, Series C, Reel 2).

${ }^{72}$ See Letter from Marian Wynn Perry to K.B. Brewer (Dec. 8, 1948) (on file with NAACP Papers, Part 13, Series C, Reel 2) (suggesting that a NAACP member of the Charleston branch advise a family to contact private counsel since "there appears to be nothing that this office can do to aid the Boyd family").

${ }^{73}$ Letter from Claude A. Barnett to Leslie Perry (May 20, 1946) (on file with NAACP Papers, Part 13, Series C, Reel 2) [hereinafter Letter from Barnett].
} 
tor of Economic Stabilization and the War Food Administrator during reconversion. ${ }^{74}$ In August 1945, that authority was conferred on the Secretary of Agriculture, Clinton P. Anderson. ${ }^{75}$ In exercising his authority, the secretary had to follow certain procedures. Local wage boards, comprised mostly of white landowners, had to "hold a public hearing for the purpose of determining whether a majority of the producers of a commodity in a particular area participating in such hearing" desired a wage ceiling. ${ }^{76}$ The boards were required to give public notice "in prominent places in the area affected, and in news stories or by paid advertisements in local newspapers of general circulation." 77 The recommendations of the wage boards were not binding on the administrator, and the administrator was not to recommend a ceiling "unless a majority of the producers of the commodity" requested it; even then, if the "majority is not representative of the entire group of producers of such commodity in the area affected the wage board may withhold its recommendation" until the preferences of the majority were clear. ${ }^{78}$

In 1945, the Department of Labor held referenda in Mississippi, Arkansas, and Missouri, and ceilings were set for the former two states. $^{79}$ Complaints about the ceilings immediately reached the NAACP not from the workers themselves, but from H.L. Mitchell of the Southern Tenant Farmers Union and from Alfred Baker Lewis, Secretary and Treasurer of the National Sharecroppers Fund and a member of the NAACP's Board of Directors. Mitchell and Lewis were up in arms. ${ }^{80}$ As Leslie Perry of the Washington office later put the

\footnotetext{
${ }^{74}$ Emergency Price Control Act of 1942, Pub. L. No. 77-421, 56 Stat. 23 (repealed 1947).

${ }^{75}$ Petition for Injunction at 1, Shackelford v. United States Dep't of Agric. (No. H257) (E.D. Ark. 1945) (on file with NAACP Papers, Part 13, Series C, Reel 2) [hereinafter Petition for Injunction, Shackelford v. USDA].

${ }^{76}$ Id. at 3; see also id. (citing Exec. Order No. 9599, 3 C.F.R. 418 (1943-1948), and setting out the full procedure for recommending the establishment of a wage ceiling).

${ }^{77} I d$

${ }^{78}$ Id.

${ }^{79}$ Statement from H.L. Mitchell, President, Southern Tenant Farmers Union, to the Secretary of Agriculture (Sept. 10, 1945) (on file with NAACP Papers, Part 13, Series C, Reel 2) [hereinafter Mitchell Statement] (noting that "[o]verwhelming votes were cast in favor of such ceilings" in these states); see also Letter from H.L. Mitchell to Leslie Perry (Dec. 7, 1945) (on file with NAACP Papers, Part 13, Series C, Reel 2) [hereinafter Letter from Mitchell to Perry] (explaining why Missouri did not set a ceiling despite this vote).

${ }^{80}$ See infra text accompanying notes 114-28, 193-99 (discussing Lewis's commitment to the race and class components of the problem in contrast to his colleagues' focus on the purely racial aspects of the situation).
} 
matter in a letter to Anderson, the farm lobby had succeeded in using "the power of your Agency ... to freeze the wages of this class of agricultural laborer at levels patently substandard." "[N] othing in the national economy, or the economy of the cotton industry ... would justify the drastic action that has been taken," she went on. ${ }^{82}$ The "action runs counter to the entire national wage policy" to enact minimum, not maximum wages. ${ }^{8.9}$ Contrary to the federal government's general movement toward improving the standard of living of workers, " $[t]$ he ceiling and the way it operated," Claude Barnett of the Associated Negro Press explained, "whipped the small Negro owner and tenant to death." ${ }^{84}$

The attack Mitchell and Lewis wanted to make on the ceilings had multiple prongs. On the broadest level they argued that the secretary generally lacked authority to impose cotton wage ceilings. The first component of this argument was rather technical. They argued that when the president modified wartime controls of prices, wages, materials, and facilities by executive order on August 21, 1945, the modification cancelled the USDA's authority to set ceilings, and the ceilings were consequently illegal. ${ }^{86}$

The second component of the lack-of-authority argument contended that the ceilings constituted an abuse of the authorizing legislation. The ceilings were meant to curb inflation by preventing wages from rising so quickly that they would affect the economy generally. But cotton workers were paid less than almost anyone in the country, so there could be no inflation-related need to regulate cotton wages. Indeed, inflation was not the target; the mobility of African American day laborers, sharecroppers, and tenant farmers was the target. Southern landlords had long ago figured out how to use first New

${ }^{81}$ Letter from Leslie S. Perry to Hon. Clinton P. Anderson (Feb. 27, 1946) (on file with NAACP Papers, Part 13, Series C, Reel 2) [hereinafter Letter from Perry to Anderson].

${ }^{82} I d$.

${ }^{83} I d$.

${ }^{84}$ Letter from Barnett, supra note 73.

${ }^{85}$ Exec. Order No. 9599, 3 C.F.R. 418 (1943-1948).

${ }^{80}$ If it was the case that only wage controls in industry had been eliminated, Lewis thought, "pressure could be brought to bear upon [President Truman] to remove similar controls in agriculture." Letter from Alfred Baker Lewis to Walter White and Thurgood Marshall (Oct. 15, 1945) (on file with NAACP Papers, Part 13, Series C, Reel 2) [hereinafter October Letter from Lewis to White].

${ }^{87}$ See Mitchell Statement, supra note 79 (“[C]otton pickers ... [and] other agricultural labor in the cotton South ... enjoy the lowest wages of any workers in the nation."). 
Deal programs, and later wartime federal programs, to their advantage. One planter boasted that "he had been able to control the practice of truckers hauling pickers to the plantation paying highest rates by virtue of being a member of the local [Office of Price Administration] rationing board ... and denying gasoline to truckers who failed to follow orders." 88 Landlords who were members of the wage labor boards thought wage ceilings could do the job more directly. The "prime purpose" of the agriculture ceilings, then, was "to keep producers from pirating employees by offers of higher wages when workers are scarce in a given area." ${ }^{, 99}$ So long as the market determined price, laborers could move freely from one place to another in response to higher wages. Wage ceilings enabled the owners to ensure a steady supply of wage labor without having to compete for it-ceilings restrained the mobility of laborers to the benefit of their employers and landlords.

Mitchell and Lewis also made a series of arguments that the ceilings were illegal due to infirmities in the procedures by which they were put in place. First, they claimed that the low voter turnout indicated that the wage boards had failed to publicize adequately in accordance with the regulations and that the vast majority of producers

\footnotetext{
88 .

${ }^{89}$ Memorandum from Leslie Perry to Mr. Dudley, Mr. Hastie, and Mr. White (Oct. 11,1945 ) (on file with NAACP Papers, Part 13, Series C, Reel 2).

${ }^{90}$ See Press Release, National Farm Labor Union (n.d.) (on file with NAACP Papers, Part 13, Series C, Reel 2) ("Statements were made by planters that they wanted a wage ceiling set so that Negro sharecroppers would not be tempted to move into town where they could earn more money as wage hands on nearby farms working 100 days a year in the chopping and picking seasons."). The National Farm Labor Union was the successor to the Southern Tenant Farmers Union. Letter from Alfred Baker Lewis to Thurgood Marshall (Jan. 2, 1946) (on file with NAACP Papers, Part 13, Series C, Reel 2) [hereinafter Letter from Lewis to Marshall]. Indeed, the Secretary of Agriculture, without any apparent awareness of the implications of his response, essentially agreed with the landowners. He described how, prior to the wage ceilings, the "supply situation" was "characterized by spiraling wage rates, pirating of workers by employers, high labor turnover and excessive loss of working time by employees going from place to place seeking the highest wage rate frequently on the basis of mere rumor." Letter from Clinton P. Anderson to Leslie Perry (Mar. 13, 1946) (on file with NAACP Papers, Part 13, Series C, Reel 2). The secretary was pleased that the institution of the ceilings yielded a "more stable" situation, in which "pirating was minimized; wages tended to become uniform ... [while w] orkers settled down to perform the specific task; and all together more food and fibre was harvested and workers were afforded the opportunity of earning more total wages." Id. The secretary thus conceded that he was using the wage ceilings not to curb inflation-which was the use for which they had been intended-but to restrict mobility.
} 
had "expressed their disapproval by not participating."91 Second, Mitchell argued, an atmosphere of intimidation pervaded both the hearings and the votes themselves. In Missouri, where the Southern Tenant Farmers' Union (STFU) was able to organize opposition to the ceilings, the wage board decided not to impose them. ${ }^{92}$ In Mississippi, however, no cotton pickers testified, ${ }^{93}$ and in Arkansas, "those who represented the point of view of labor were subjected to insult and intimidation. ${ }^{94}$ The voting proved problematic in a number of ways. In more than one county in Arkansas, "a group of small farm owners, tenants, and sharecroppers ... having [been] notified of the time and place to cast their ballots, waited throughout the day and no one appeared to conduct the referendum. ${ }^{, 95}$ More generally, thought Mitchell, the lack of a "provision in the regulations for a secret ballot" allowed "plantation owners to herd their sharecroppers into the polls and force them to vote as they saw fit." ${ }^{, 96}$ Many sharecroppers were intimidated into voting in favor of the referendum by landlords with control over their livelihoods, their homes, and even, as the cases above indicated, their lives. ${ }^{97}$

The third procedural challenge was potentially the most theoretically and doctrinally significant. Mitchell claimed that limiting voting rights on the ceilings to "producers," and defining the term to exclude the wage workers who would be directly affected was unconstitutional. The referenda were "illegal because the people whose wages are being set have no right to vote on the question.",98 It was not entirely clear whether the problem lay in the legislation itself or in its interpretation by the wage boards and the secretary. Claude Barnett of

${ }^{91}$ Petition for Injunction, Shackelford v. USDA, supra note 75, at 4; see Mitchell Statement, supra note 79 (observing that the vote in Arkansas was 9356 for a ceiling and 2757 against, but the total number of farmers and farm operators in the counties holding the referendum was 84,377 , and thus less than one-seventh of the eligible voters had participated).

${ }^{92}$ Letter from Mitchell to Perry, supra note 79.

93 Id: Mitchell Statement, supra note 79.

${ }^{94}$ Mitchell Statement, supra note 79.

${ }^{95}$ Id.

${ }^{96}$ Statement from H.L. Mitchell to USDA State Wage Stabilization Board Meeting, Establishing a Wage Ceiling for Chopping Cotton (Mar. 6, 1946) (on file with NAACP Papers, Part 13, Series C, Reel 2) [hereinafter Mitchell Statement to USDA].

${ }^{97}$ See Mitchell Statement, supra note 79 (describing the Mississippi vote of 21,982 in favor and 315 against as akin to fascist votes); October Letter from Lewis to White, supra note 86 ("[J] udging from the vote, either the wage workers were not included, or else they were subjected to intimidation and/or misrepresentation as to what they were voting on.").

${ }_{98}$ Mitchell Statement to USDA, supra note 96. 
the Associated Negro Press thought that "[w]hile these state committees are not directed specifically to receive the laborers point of view, it is my understanding that they have assumed that to be a proper function." ${ }^{\prime 9}$ Lewis agreed "that the 'producer[]' of a commidity obviously does not and legally should not exclude the wage workers in that line." ${ }^{100}$ Regardless of the origins of excluding the wage laborers, Leslie Perry concluded that a law that excludes them is " $[n]$ ot only... undemocratic in that it does not give the workmen a real voice in determining what he shall earn, but we think that it invades basic rights guaranteed to him by our Constitution."

Mitchell's final argument was a substantive one. He claimed that it was "an absurdity for the Secretary of Agriculture to impose a ceiling on wages of cotton pickers or any other agricultural labor in the cotton South since they enjoy the lowest wages of any workers in the nation." ${ }^{102}$ Articles in the STFU's Farm Labor News emphasized the poverty of southern farm workers-their need for better housing, education, health care-and showed that farm workers should earn more than they did, not less. The STFU therefore "advanced a demand for a guaranteed annual wage of $\$ 625$ per family for all farm labor ... based on the idea that no adult worker should earn less than $\$ 5$ per 10 hour day on the farm."

These arguments, in one form or another, all found their place in a brief the STFU filed on behalf of the cotton farmers in federal court in the Eastern District of Arkansas. ${ }^{104}$ Unfortunately for the workers, the brief was under-researched, poorly written, and lacking both solid supporting facts and much legal analysis. The lawyer, as Lewis put it in his efforts to get the NAACP's legal department involved, though "thoroughly in sympathy" with the STFU, "may not be competent to handle the constitutional question which may be involved." ${ }^{105}$ In fact, despite the substantial rights claims nascent in the various arguments-involving the meaning of "producing" wealth, a minimum wage for human survival, the right to earn a livelihood as a market actor in an allegedly free market economy, and the right to vote (less as

${ }^{99}$ Letter from Barnett, supra note 73.

${ }^{100}$ Letter from Lewis to White, supra note 86.

${ }^{101}$ Letter from Perry to Anderson, supra note 81.

${ }^{102}$ Mitchell Statement, supra note 79.

${ }^{103}$ Id

${ }^{104}$ Petition for Injunction, Shackelford v. USDA, supra note 76.

${ }^{105}$ Letter from Alfred Baker Lewis to Walter White (Oct. 23, 1945) (on file with NAACP Papers, Part 13, Series C, Reel 2). 
a matter of racial equality than as a matter of class equality)-Lewis conceded that the brief was "probably puerile and futile." In response, the United States moved to dismiss the case on no less than five separate grounds, including failure to state a claim upon which relief could be granted. ${ }^{107}$ The district court did in fact dismiss, but on a much narrower and more easily surmountable ground: the Secretary of Agriculture was a necessary party to the action and service could not be had against him in the district in which the plaintiffs had chosen to initiate suit. ${ }^{108}$ The farmworkers could thus gain another chance to develop their arguments by filing suit against the secretary in Washington, D.C.

Throughout 1945 and 1946, Lewis and Mitchell tried to get the NAACP to take ownership of the case. Lewis wrote that it seemed to him "that the N.A.A.C.P. ought to be in on it as nearly on the ground floor as possible especially since we have more in resources, legal ability, and ability to reach the daily papers than has the STFU."109 Involvement initially looked promising, as Lewis had obtained the following resolution:

The National Board of the N.A.A.C.P. opposes setting wage ceilings for cotton picking, by a vigorous campaign of publicity, by enlisting the aid of organized labor where possible, and by political pressure on the Secretary of Agriculture and on the President; and we instruct the Legal Department to explore possible avenues of legal attack on such wage ceilings. $^{110}$

Within the Inc. Fund's taxonomy of case significance-measured as local, state, or national-the wage ceilings fell somewhere between state and national, ${ }^{111}$ a position that seemed to call for action. Moreover, if not univalent, the fact that "[n]early all [affected were] Negroes"112 pointed toward the salience of race. At least on the level of

${ }^{106}$ Letter from Lewis to Marshall, supra note 90.

107 Motion to Dismiss Complaint, Shackelford v. United States Dep't of Agric. (E.D. Ark. 1945) (No. H-257) (on file with NAACP Papers, Part 13, Series C, Reel 2).

${ }^{108}$ Letter from Mitchell to Perry, supra note 79.

${ }^{109}$ Letter from Alfred Baker Lewis to Walter White (Nov. 1, 1945) (on file with NAACP Papers, Part 13, Series C, Reel 2).

${ }^{110}$ Minutes of the October NAACP Board of Directors Meeting (Oct. 17, 1945) (on file with NAACP Papers, Part 13, Series C, Reel 2).

"See id. (pointing out how nineteen counties in Mississippi had ceilings and how the movement was spreading).

${ }^{112}$ Mitchell Statement to USDA, supra note 96. 
rhetorical commitment, the NAACP professed that it was "deeply interested" in the issue."

But from relatively early on, the prospects for aggressive and substantial NAACP action looked poor. Lewis had a hard time getting either the political or the legal staff actually to act. "Because of the complexity of the problem involved and our work on other cases at the moment," the legal department told the STFU that it could not support the initial lawsuit. ${ }^{114}$ In fact, the legal department decided not only that the STFU's brief was not "adequate enough to challenge the position of the agricultural department in this matter" 115 but also, on the basis of that "inadequate" brief and little additional research, that the case had no merit. ${ }^{116}$ Instead of legal action, Thurgood Marshall suggested that Leslie Perry of the Washington office put political pressure on the USDA. ${ }^{117}$ But Perry told a skeptical Lewis that he should wait for the outcome of the STFU's legal case before lobbying the secretary. ${ }^{18}$ Even when Walter White told Perry to follow up on Lewis's suggestion that the NAACP involve the unions, which might argue "in opposition to the principle of setting wage ceilings under the circumstances provided by the law which do not give any effective opportunity to the workers concerned to be heard,"119 the Advisory Committee

${ }^{113}$ Letter from Perry to Anderson, supra note 81.

114 Letter from Edward R. Dudley, Assistant Special Counsel, NAACP, to H.L. Mitchell, President, Southern Tenant Farmers Union (Oct. 30, 1945) (on file with NAACP Papers, Part 13, Series C, Reel 2).

${ }^{115}$ Letter from Edward R. Dudley, Assistant Special Counsel, to Alfred Baker Lewis (Oct. 30, 1945) (on file with NAACP Papers, Part 13, Series C, Reel 2).

${ }^{116}$ Letter from Edward R. Dudley, Assistant Special Counsel, NAACP, to Leslie Perry, Administrative Assistant, NAACP Washington Bureau (Oct. 26, 1945) (on file with NAACP Papers, Part 13, Series C, Reel 2). The latter conclusion grew out of an exceedingly narrow conception of the possible arguments that could be presented. Edward Dudley limited himself to the technical question of whether the secretary's authority had expired. He concluded:

It seems to me that if the existing war time legislation granting to the President the power to promulgate certain laws and regulations designed to check prices, etc. have not terminated either by act of Congress or Presidential order, that these controls might very well be held constitutional at this time as necessary legislation to control reconversion, particularly in view of the fact that Congress has not officially declared the end to the war.

Id.

117 Memorandum from Thurgood Marshall to Leslie Perry (Jan. 3, 1946) (on file with NAACP Papers, Part 13, Series C, Reel 2).

${ }^{118}$ Letter from Leslie Perry to Alfred Baker Lewis (Nov. 30, 1945) (on file with NAACP Papers, Part 13, Series C, Reel 2)

119 Letter from Alfred Baker Lewis to Leslie Perry (Mar. 22, 1946) (on file with NAACP Papers, Part 13, Series C, Reel 2). 
of the Washington Bureau still refused to take responsibility. ${ }^{120}$ Seeing no need for its own lobbying activities, the committee recommended studying the possibilities for a lawsuit. ${ }^{121}$

Lewis kept pushing, reminding Walter White that the board of directors had resolved to act and that nothing much had been done. ${ }^{122}$ He tried to convince the Inc. Fund that it could shape the case itself, in any direction. Lewis believed if the Inc. Fund would

attack the problem from the point of view of bringing the proper suit or having the proper suit brought rather than from the point of view of approving or disapproving the legal efforts of the STFU, that organization will agree to any suggestion or proposal that you are likely to make for legal action in some other form.

He emphasized that the Inc. Fund could get involved "not necessarily through support of the STFU but as an amicus curiae or through a suit of our own which would be consolidated with the hearing of the other suit before a higher court."

In the end, the steps the NAACP took were far less substantial than submitting an amicus brief. Marian Wynn Perry of the legal department told a new attorney hired by the STFU, with the help of the Workers Defense League, to keep her apprised of its plans so that the Inc. Fund could "take supporting action." ${ }^{125}$ But as it was too late for legal action to affect the 1945 season, and the ceilings expired before the 1946 season, none was ever taken. Marian Perry also reached out to the Chief Attorney of the Regional War Labor Board, Tom O'Brien, who told her that he "could see no reason why wage controls in agriculture should continue as stringent as ever when wage controls

120 See Memorandum from Leslie Perry to Walter White (Apr. 17, 1946) (on file with NAACP Papers, Part 13, Series C, Reel 2) (basing its decision not to pursue the case on the "enormous pressure now being brought by the large bloc of cotton state representatives," "the apparent legality of the Department's action," and the lack of "information ... indicating local (community) suffering or indignation on account of the imposition of ceilings").

${ }^{121}$ Id.

${ }^{122}$ See Letter from Alfred Baker Lewis to Walter White (Dec. 27, 1945) (on file with NAACP Papers, Part 13, Series C, Reel 2) (stressing the importance of combating wage ceilings and dismissing any possible reasons for the NAACP's "hesitation or delay").

Letter from Lewis to Marshall, supra note 90.

${ }^{124}$ Letter from Alfred Baker Lewis to Walter White (Nov. 1, 1945) (on file with NAACP Papers, Part 13, Series C, Reel 2) [hereinafter November Letter from Lewis to White].

Letter from Marian Wynn Perry, Assistant Special Counsel, to Joseph Freeland (Jan. 2, 1946) (on file with NAACP Papers, Part 13, Series C, Reel 2). 
in industry had been lifted." ${ }^{126}$ Leslie Perry wrote a single letter to Clinton Anderson, the Secretary of Agriculture. ${ }^{127}$ These three actions-two government contacts and the possibility of "supporting action" in a lawsuit that never materialized-constituted the sum total of NAACP involvement. Lewis "confess[ed] defeat by the invincible inertia of the National Office in my attempt to get them to follow out the Board's specific instructions and take some action in opposition to the wage ceilings." ${ }^{28}$ The grudging steps the office had taken compared poorly with the vast legal and political campaign to protect the livelihood and mobility of black agricultural workers Lewis had had in mind.

\section{IV. "THE APPEARANCE OF FREEDOM BUt CERTAINLY NOT THE REALITY": ${ }^{129}$ PEONAGE, INVOlUnTARY SERVITUde, AND DIRECT CONTROLS ON MOBILITY}

Personal mobility was even more directly threatened in the final set of cases that leaps out from the archives-those involving involuntary servitude. Where employers hoped to obtain labor and property with minimal expenditure in the property cases and to curtail mobility by making it less profitable for farmworkers to move in the wage ceiling case, the white employer's desire in involuntary servitude cases was to obtain costless, or nearly costless, labor through the complete elimination of the worker's mobility. In response, African Americans throughout the South (and a few elsewhere) complained to the NAACP about "violat[ions] under the Federal Civil Rights statute and under the Thirteenth Amendment to the Constitution."

While some of the complaints did not specify what their victims meant by "peonage," "involuntary servitude," or "slavery" but simply asserted the condition and the need for help, ${ }^{131}$ others challenged

${ }^{126}$ Memorandum from Marian Wynn Perry to Thurgood Marshall (Jan. 7, 1946) (on file with NAACP Papers, Part 13, Series C, Reel 2).

${ }_{127}$ Letter from Perry to Anderson, supra note 81.

${ }^{128}$ Letter from Alfred Baker Lewis to Leslie Perry (May 28, 1946) (on file with NAACP Papers, Part 13, Series C, Reel 12).

${ }^{129}$ Letter from Milton R. Konvitz, Assistant Special Counsel, to Leslie Perry, NAACP Washington Bureau (July 8, 1943) (on file with NAACP Papers, Part 13, Series C, Reel 12) [hereinafter Letter from Konvitz].

130) Letter from Harold D. Snell to Luther M. Swygert, Assistant United States Attorney, Hammond, Ind. (Sept. 11, 1947) (on file with NAACP Papers, Part 13, Series C, Reel 12).

${ }^{131}$ See Letter from Mrs. Erma J. Jenkins to NACCP [sic] (Nov. 26, 1946) (on file with NAACP Papers, Part 13, Series C, Reel 12) ("I have been informed that you could 
specific mechanisms of force and coercion or focused on what they deemed the essential characteristics of slavery-like employment. Many of the complaints concerned "peonage" proper, where a laborer was forced to work for a particular employer to repay a debt to that employer. The debt itself could arise in any number of ways. Sometimes wage laborers complained that they had to pay their employers exorbitant prices for travel, food, or shelter that their wages were unable to cover. $^{132}$ One letter reported a large farm on which the owner held fifteen or twenty African Americans, paying them a very small amount, charging them excessively at his own commissary, and working them "long, hard hours." ${ }^{33}$ Often, even though peonage was not only contrary to the Thirteenth Amendment in some abstract sense but also subject to criminal penalties actually imposed by the federal government since the early twentieth century, ${ }^{134}$ employers made little effort to hide their intent. Thus one employer wrote to the sister of a man he was holding, "[Your brother] is in my debt. He owes me \$75.00. He cannot leave this island until I receive my money."

Others complained that they were the victims of trumped-up criminal charges. In one common scenario, the employer would pay the employee's fine and then require the worker to work off the debt

abide me in relieving my Daughter from almost slavery which she has been for seven years.").

${ }^{192}$ See Press Release, NAACP, [entitled] Department of Justice (Nov. 4, 1942) (on file with NAACP Papers, Part 13, Series C, Reel 12) (discussing peonage at the United States Sugar Corporation, which forced workers to pay off transportation and other debts).

${ }^{133}$ Letter from C.B. McCullar to Roger Baldwin (May 19, 1941) (on file with NAACP Papers, Part 13, Series C, Reel 12).

${ }^{194}$ See, e.g., United States v. Gaskin, 320 U.S. 527, 528-29 (1944) (holding the defendant liable under 18 U.S.C. $\$ 1581(2000)$, and finding that "placing a person in ... a condition of peonage was one of the evils to be suppressed" by the statute); United States v. Reynolds, 235 U.S. 133, 144, 150 (1914) (finding a system enabling private employers to pay fines and court costs of defendants who pled guilty and then requiring the defendants to work off their debt to the employers under threat of rearrest violative of the Thirteenth Amendment and other federal statutes). See generally, Goluboff, supra note 5, at 1638-39 (discussing the Peonage Act of 1867, Act of Mar. 2, 1867 , ch. 187, $\S 1,14$ Stat. 546 (codified as amended at 42 U.S.C. $\$ 1994(2000)$ ), and its enforcement).

${ }^{135}$ Letter from William Lucas to Sister of Charlie Stubbs (Mar. 21, 1943) (on file with NAACP Papers, Part 13, Series C, Reel 12); see also Letter from Officer Edward L. Nixon, Chicago Police Dept., to Steven B. McCord, Chicago (n.d.) (on file with NAACP Papers, Part 13, Series C, Reel 12) (complaining that Nixon's brother had been accused of a debt and threatened with murder on a plantation and that his wife was still held there in a "modern slave system"). 
in his employ. ${ }^{136}$ Arthur Shores, a black attorney and prominent member of the NAACP in Birmingham, Alabama, described another scenario involving manipulation of the criminal justice system:

It seems to be a common thing now since farm labor is so scarce to trump up any sought of a charge in order to put Negroes in jail in the farming areas then let them out without finally settling their cases, and if they leave these farming districts, have them returned on the pretext that they are either fugitives or probation violators. ${ }^{137}$

One merchant who helped a parolee procure a job found out the power of such schemes a little too late. He reported, "Well changing jobs is not considered a felony anywhere in America so I took [the] threat [of rearrest] lightly, but sure enough a deputy Sheriff came and returned Pope to Parchman [prison], and there he is now."1.8 Milton Konvitz recognized the paradox of the parole cases when he stated:

The person is not working off a debt or a fine. He was sentenced to life imprisonment, and given a parole on condition of his working on a farm. The involuntary servitude comes in only with respect to the absence of a choice of employment, and also with the fact that the parole, conditioned as it was, gave him only the appearance of freedom but certainly not the reality.

During the war another legal weapon was added to the planters' arsenal. Numerous municipalities passed, and many others enforced informally, so-called "work or fight" laws, in which "police officers . . form [ed] a 'Gestapo' to force local Negroes to the cotton fields." Both those with and those without jobs were treated as vagrants and forced to work in agriculture; they could be, and frequently were, jailed for refusing to do so. The NAACP had

${ }^{136}$ See Letter from Rev. Aron S. Gilmartin, Chairman, National Executive Board, Workers Defense League, to Walter White (June 22, 1944) (on file with NAACP Papers, Group II, Box A468, Folder in General Office File, Peonage General 1941-1955) (telling of eighteen African American women in Oakland Park and twenty-four men in Fort Lauderdale who were arrested for protesting their low wages and then released into the debt of their employers); see also Reynolds, 235 U.S. at 133, 139-40 (describing the cases of Ed Rivers and E.W. Fields who were fined $\$ 43.75$ and $\$ 69.70$, respectively, and then forced into involuntary servitude).

${ }^{197}$ Letter from Arthur D. Shores to Thurgood Marshall (Feb. 24, 1943) (on file with NAACP Papers, Part 13, Series C, Reel 12).

${ }^{198}$ Letter from W.J. Lacy, Merchant and Planter, Lyon, Miss., to William Henry Huff (n.d.) (on file with NAACP Papers, Part 13, Series C, Reel 12).

${ }^{139}$ Letter from Konvitz, supra note 129.

${ }^{140}$ Letter from A. Maceo Smith, Secretary, NAACP, to Thurgood Marshall, Special Counsel, NAACP (Nov. 7, 1945) (on file with NAACP Papers, Part 13, Series C, Reel 12). 
information that large farmers and county police officials, in an effort to stop Negro farm workers from leaving the area for more lucrative employment in industrial centers, have resorted to placing them under arrest on spurious charges and when unable to pay fines requiring [them to] ... work on local plantations. ${ }^{141}$

Others complained that they were kept in particular jobs through violence, force, or intimidation exercised by the landowner directly on the employee without the mediation of either an alleged debt or a criminal proceeding. One woman wrote for help getting her aunt and uncle

from some old white farmer out from Maco Miss thay got the children tied to the Bed lef and whip them ... oh thay are under slavery please Do some thing for them ... we are afraid to go at there ... thay are liveing in the yard with the old white people. ${ }^{142}$

Still other workers complained of being beaten with cat-o-nine tails or hoses. ${ }^{143}$ For some, the immobility that accompanied such treatment was so severe that they perceived themselves to "belong" to their employers. $^{144}$

Finally, some complaints about peonage, slavery, or involuntary servitude focused less on the legal means by which employers kept employees immobilized and more on the conditions in which the employees worked and lived. Some letters in this category, like most in the other categories, concerned male agricultural workers. Lucy Graves in Poughkeepsie, New York, for example, told the NAACP about "Negroes who had been imported from Florida [and] were working in terrible conditions," a "serious situation which is illegal in the state." Other complaints, however, especially in the later 1940s, came from female domestic workers like Elizabeth Coker. ${ }^{146}$ Coker and those who came into contact with her described the "actual slav-

${ }^{141}$ Press Release, NAACP, NAACP Urges Justice Dept. to Investigate Peonage (May 28, 1943) (on file with NAACP Papers, Part 13, Series C, Reel 12); see also Maryland "Peonage" Studied, Heral.d TriB., Sept. 27, 1943 (on file with NAACP Papers, Part 13, Series C, Reel 12) (discussing Maryland's "work or fight" law).

${ }^{142}$ Letter from Willie May Washington, Hattiesburg, Miss., to the NAACP (May 12, 1941) (on file with NAACP Papers, Part 13, Series C, Reel 12).

"Li3 Letter from George Tailor to "Gentlemen" (Aug. 29, 1941) (on file with NAACP Papers, Part 13, Series C, Reel 12).

${ }^{144}$ Frank McCallister, Report on Peonage at Sealy Springs 2 (Jan. 15, 1942) (on file with NAACP Papers, Part 13, Series C, Reel 12).

${ }^{145}$ Letter from Lucy Graves to Thurgood Marshall (Aug. 9, 1940) (on file with NAACP Papers, Part 13, Series C, Reel 12) [hereinafter Letter from Graves].

${ }^{146}$ See generally Goluboff, supra note 5, at 1663 ("The women emphasized lack of pay, degrading conditions, and hard work."). 
ery" in which she lived, working long hours at labor thought inappropriate for a nineteen-year-old woman for little or no pay, forced to sleep in a chicken coop without a bathroom, and lacking access to education, church, or visitors. As she put it, "In all the time I was in the Franklin home I never enjoyed any privileges of a free person." Polly Johnson's situation was similar. One observer wrote:

[S] ome white folks raised [her] as a slave without the knowledge of her age and no schooling and her hands look like they have been cracked open with corns and callouses from hard labor and she says that she has been whipped with lashes and treated real cruel and slept in a chicken house and rain on her bed, and in fact the way the girl acts, she has been treated even worse than she can explain. ${ }^{148}$

In these accounts, the employers certainly used physical violence, but the oppressive nature of the working and living conditions served as the basis for many of the complaints.

Few in or in contact with the NAACP seemed to doubt how widespread or deep-seeded these practices were in the 1940 s South. ${ }^{149}$ One branch saw the phenomenon as "a revival of the old fugitive slave act" and thought "that the policy of the government to freeze agricultural labor in the South will permit unscrupulous whites to enslave Negro labor on the pretense of carrying out regulations of the non-migratory labor on farms." 150 Reports from various organizations urging the NAACP to join the fight against peonage and involuntary servitude

${ }^{147}$ Affidavit of Elizabeth Coker, El Paso County, Tex. (Jan. 30, 1947) (on file with NAACP Papers, Part 13, Series C, Reel 12).

${ }_{148}$ Letter from Miss Mattie Lomax, D.C., to NAACP (Mar. 10, 1946) (on file with NAACP Papers, Part 13, Series C, Reel 12).

${ }^{149}$ The Guide to the relevant NAACP Papers collection gives a good sense of how widespread and geographically diverse the complaints were. It lists complaints from Georgia, New York, Texas, Arkansas, Virginia, and Florida, among other states. A Guide to the Microfilm Edition of PAPERS OF the NAACP, PART 10: PEONAGe, LABOR, AND THE NEW DEAL 1913-1939 (John H. Bracey, Jr. \& August Meier eds., 1990); see also Letter from Knott to Perry (Nov. 18, 1947) (on file with NAACP Papers, Part 13, Series C, Reel 12) (discussing several "cases of slavery" and people "still in bondage"); Letter from Carolyn M. Davenport, Executive Secretary, Philadelphia branch, NAACP, to Walter White (July 14, 1943) (on file with NAACP Papers, Part 13, Series C, Reel 12) ("I wonder how many more cases like this exists in Virginia."); Confidential Memorandum on Alleged Peonage in Milledgeville, Georgia (July 9, 1942) (on file with author) [hereinafter Milledgeville Memorandum] (communicating the widely held belief that a member of the community was running a peonage farm).

${ }^{150}$ Letter from Mrs. Julius White, Executive Secretary, Houston branch, NAACP, to Thurgood Marshall (May 25, 1943) (on file with NAACP Papers, Part 13, Series C, Reel 12) [hereinafter Letter from Mrs. Julius White]. 
also proclaimed the prevalence of such practices. The Workers Defense League described how

[p] eonage conditions in our own country exist in many sections of the Deep South where intimidation and often violence are used to keep sharecroppers and day laborers in virtual slavery despite a Supreme Court ruling of long standing that it is contrary to the Thirteenth Amendment to exact forced labor because of actual or alleged debt. ${ }^{151}$

And when investigating a case for the NAACP in Milledgeville, Georgia, Frank McCallister found the peonage charges "are undoubtedly true as they are against a great many landowners in Georgia."152

The NAACP responded to involuntary servitude cases more often and with greater energy than either the property cases or the wage ceiling fight. Certainly, the NAACP did not see peonage as merely a "private" problem. Staff members noted how the individual incidents about which the letters often complained were part of a larger assault on the mobility of African American workers in the South as a group. Wrote Leslie Perry, "The land owners are quite worried about the wages they will have to pay and the amount of labor they will have at their disposal. This seems to be the main reason why there is a growing antagonism against the [Negroes]."153 Clarence Mitchell referred specifically to "restrictions of the free movement of labor in the South," and to "Southern growers [who] fear that workers who leave will not return." 154

The national office nonetheless relegated many involuntary servitude cases to the branches, ${ }^{155}$ a responsibility the branches often had good reasons for wanting to lay at the door of the national office. Before Thurgood Marshall even had the chance to suggest that Lucy Graves of Poughkeepsie should refer a peonage matter to the state authorities herself because "you are nearer to the situation than we are here," 156 she had written:

151 Statement from Workers Defense League to the United Nations (Dec. 18, 1947) (on file with NAACP Papers, Part 13, Series C, Reel 12).

${ }^{152}$ Milledgeville Memorandum, supra note 149.

${ }^{15.3}$ Memorandum from Leslie S. Perry to Victor Rotnem (May 27, 1943) (on file with NAACP Papers, Part 13, Series C, Reel 12).

${ }^{154}$ Press Release, NAACP, Alien Workers Not Needed, Mitchell Tells Committee (July 20, 1950) (on file with NAACP Papers, Part 13, Series C, Reel 12).

${ }^{155}$ See, e.g., Letter from Frank D. Reeves, Legal Research Assistant, to Henry Flowers, Jr. (Aug. 13, 1941) (on file with NAACP Papers, Part 13, Series C, Reel 12) [hereinafter Letter from Reeves] (referring a letter to the local branch because the branch would be better able to help).

${ }^{156}$ Letter from Thurgood Marshall to Miss Lucy Graves (Aug. 12, 1940) (on file 
Do not suggest that a branch of the NAACP up this way work, as the branch is absolutely inactive, beside this group of people are not familiar with the proper procedures for conducting such an investigation, nor do most of them have the time, as you must know something about the employment situation facing all Negroes here. ${ }^{157}$

The Houston branch, trying to help a runaway from Arkansas, suggested another reason why branches may not have been able to address peonage cases adequately: "We think this case should be handled by the national office so that the necessary machinery for getting evidence from Arkansas concerning the number of persons still practically enslaved on this same farm can be obtained."

More commonly, the NAACP investigated the case enough to ensure its veracity, and then it recommended that the Civil Rights Section of the Department of Justice prosecute. ${ }^{159}$ Highly publicized peonage cases in the early twentieth century and during World War II brought by private parties other than the NAACP do not seem to have inspired the Association to bring its own. ${ }^{160}$ As Justice Jackson explained in Pollock $v$. Williams, "Congress raised both a shield and a sword against forced labor because of debt." The sword consisted of the criminal laws under which prosecutions could be brought against individual perpetrators, and the shield was the defense to the use of

with NAACP Papers, Part 13, Series C, Reel 12).

${ }^{157}$ Letter from Graves, supra note 145.

158 Letter from Mrs. Julius White, supra note 150.

${ }^{159}$ See Letter from Thurgood Marshall to Thomas H. Browne, President, Phoenix Branch (Aug. 11, 1941) (on file with NAACP Papers, Part 13, Series C, Reel 12) (referring a complainant to the local United States Attorney); Letter from Thurgood Marshall to Frank McCallister (June 5, 1941) (on file with NAACP Papers, Part 13, Series C, Reel 12) (calling upon Frank McCallister to do the "preliminary investigation prior to referring [the matter] to the Department of Justice").

${ }^{160}$ See, e.g., Pollock v. Williams, 322 U.S. 4, 25 (1944) (finding that two Florida fraud statutes effectively caused Pollock to be in a state of peonage and therefore ruling them void); Taylor v. Georgia, 315 U.S. 25, 31 (1942) (holding "that the sections of the Georgia Code upon which this conviction rests are repugnant to the Thirteenth Amendment," and reversing the underlying conviction); Bailey v. Alabama, 219 U.S. 219, 245 (1911) (invalidating an Alabama statute because it violated the Thirteenth Amendment); see also, e.g., THE NAACP AND LABOR, 1940-1955 (John H. Bracey, Jr. \& August Meier eds., 1991) (on file with NAACP Papers, Part 13, Series C) ("There are a large number of peonage complaints included . . . . Few of the complaints are well developed because peonage is a federal offense, and the NAACP only reported the complaints to the Justice Department instead of attempting to bring suits itself."); Letter from Thurgood Marshall to Arthur Shores (Mar. 3, 1943) (on file with NAACP Papers, Part 13, Series C, Reel 12) ("Please bear in mind that the Department of Justice and the FBI are very anxious to prosecute all worthy peonage cases and it is up to us to keep feeding them these cases.").

${ }^{161} 322$ U.S. at 8. 
peonage-facilitating laws. Rather than limiting itself to referring criminal cases to the Department of Justice, then, the Inc. Fund also could have brought civil suits against individual employers under the Thirteenth Amendment, defended victims of labor-fraud statutes, and challenged the various statutes that legalized and facilitated the holding of African Americans in involuntary servitude.

For the most part, the possibility of private litigation does not seem to have occurred to the Inc. Fund, even under the most obvious circumstances. In one case Marian Wynn Perry described as "present[ing] a situation about as close to peonage as one can get," she wondered "whether there is any action that can be taken?" 162 She decided, "It certainly would not be legal action but perhaps an investigation and some publicity might help these poor souls." In another case, investigated by Frank McCallister of the Workers Defense League for the NAACP, McCallister wrote Marshall that although "it is widely believed in the community that Negroes who work for [the alleged perpetrator] find it very difficult to get away from his place once they agree to work there[,] ... there is no actual evidence of peonage which would warrant Federal prosecution." "Even though one victim was being prosecuted under the very "cheating and swindling" labor contract law the Supreme Court would strike down in the shield case of Taylor $\%$. Georgia shortly thereafter, ${ }^{165}$ neither McCallister nor Marshall saw any role in the case for Inc. Fund private initiative.

${ }^{162}$ Letter from Marian Wynn Perry to Roy Wilkins (May 12, 1947) (on file with NAACP Papers, Part 13, Series C, Reel 12).

163 Id.

${ }^{164}$ Milledgeville Memorandum, supra note 149.

${ }^{165} 315$ U.S. at 26.

${ }^{166}$ Milledgeville Memorandum, supra note 149. McCallister even explicitly stated that since the Department of Justice had become more vigorous in its prosecution of peonage cases, less work was required for the private organizations. "Under different circumstances I would have done a more thorough [investigation] but with $\mathrm{Mr}$. Biddle's announced policy on peonage you should have no trouble getting them in on the basis of this [report]." Letter from Frank McCallister to Thurgood Marshall (Jan. 15, 1942) (on file with NAACP Papers, Part 13, Series C, Reel 12).

The NAACP, International Labor Defense, and other groups found the Department of Justice initially unresponsive, and their letters frequently complained that the Department was dragging its feet. See, e.g., TUSHNET, supra note 7, at 50 (discussing how NAACP Assistant Special Counsel Marian Wynn Perry would refer to the "'usual brush-off from the Department," and observing that "the NAACP's legal staff was frustrated by its inability to secure action by the Department of Justice"); Letter from Thurgood Marshall to Hon. Vito Marcantonio, President, International Labor Defense (Mar. 9, 1942) (on file with NAACP Papers, Part 13, Series C, Reel 12) ("For quite some time, we have repeatedly requested affirmative action by the United States Department of Justice in this and other peonage cases."); Press Release, NAACP, ACLU, 
At other times, the possibility was known but left unpursued. Thus the branch involved in the Elizabeth Coker case of the young woman held by a family in "actual slavery" did contemplate bringing a civil suit. Franklin Williams of the legal department told the branch:

Your procedure to date in retaining a private attorney to investigate and report and to institute civil action is perfectly all right. Please ask Mr. Faulk, however, to forward the affidavits and whatever other information he obtains to this office so that we may send them to the Department of Justice. I believe in this manner we can bring more pressure to bear upon them with a view towards spurring them into action. ${ }^{167}$

Once the case was referred to the government, it does not appear the branch followed up on its plans for a civil suit. Thus, although the Inc. Fund saw the importance of involuntary servitude cases and could envision legal action regarding them, that action was not its own. ${ }^{168}$

Southern Committee for People's Rights, Workers' Defense League (n.d.) (on file with NAACP Papers, Part 13, Series C, Reel 12).

By 1941, Marshall could conclude that the Department was "moving swiftly on these peonage cases throughout the south... [I] t is quite clear that they are really beginning to move, and we should see some very good results in the near future." Letter from Thurgood Marshall to William Henry Huff (Dec. 16, 1941) (on file with NAACP Papers, Part 13, Series C, Reel 12); see also William H. Hastie \& Thurgood Marshall, Negro Discrimination and the Need for Federal Action, LAW. GuILD REv., Nov. 1942, at 21, 23 ("The U.S. Department of Justice is maintaining a vigorous campaign against peonage which has resulted in several successful prosecutions. There are many now pending. The Department should be commended for this.").

${ }^{167}$ Letter from Franklin Williams to White (Feb. 27, 1947) (on file with NAACP Papers, Part 13, Series C, Reel 12).

${ }^{168}$ Rarely, the NAACP would attempt to do some research into the legality of particular practices, as when Marian Wynn Perry wrote a law professor at the University of North Carolina to ask whether it was an abuse of the parole system to release a prisoner to a sponsor and then keep him at work for the sponsor. Letter from Marian Wynn Perry, Assistant Special Counsel, to Herman L. Taylor, Department of Law, North Carolina College for Negroes (Sept. 17, 1946) (on file with NAACP Papers, Part 13, Series C, Reel 12). The evolution of the Civil Rights Section's own cases show the possibilities for a more aggressive civil litigation program concerning peonage. As the 1940s progressed, the Civil Rights Section gradually expanded the kinds of cases it saw as creating involuntary servitude. First it moved past the requirement that debt be involved, considering cases in which violence, force, or intimidation without the veneer of contract kept people in servitude. Then it moved even further afield to attack the laws that enabled southemers to limit the mobility of African Americans through various facially race-neutral laws. Finally, it began an attack on the conditions in which some employers kept individual African American employees, suggesting that forcing someone to live below certain minimal conditions violated the Thirteenth Amendment. See Goluboff, supra note 5, at 1654-68 (outlining the shifting contours of the Civil Rights Section's attack on peonage). 


\section{RightS IN THE RACIALIZED POLITICAL ECONOMY OF THE AGRICULTURAL SOUTH}

In peonage and involuntary servitude cases, as in the property cases and the wage ceiling issue, the Inc. Fund ultimately passed the buck-if not to the individual's private means or the branch, then to another organization, the Department of Justice, or other government agencies. It is not that the Inc. Fund did not care about these issues; its periodic actions toward resolution, referral, or publicity show it cared at least to some extent. Rather, it appears that these issues were never on the table for the Inc. Fund's own developing litigation strategy. As NAACP lawyers contemplated their attack on racial inequality in the 1940s, labor-related inequality as experienced by African Americans working in southern agriculture stood outside their framework. The defining feature of that framework, as the Inc. Fund described it, was "injustice because of race." ${ }^{\text {"169 }}$ The phrase itself is ambiguous, as it can mean either that race was the sole cause of the injustice or one of a number of causes. To the Inc. Fund, however, race discrimination was clearly univalent. Race was not a necessary cause, not a sufficient cause, not a but-for cause: it was the only cause.

The kind of labor and employment cases the Inc. Fund took in the 1940s shows precisely this exclusive definition of race discrimination. The three sets of cases in which the Inc. Fund became most involved were quite similar. The first, which it joined at a late stage in the proceedings, concerned litigation brought by black railroad workers against white railroad unions. ${ }^{170}$ In these cases, the union and the employer signed a contract the effect of which was to eliminate African Americans as employees on the railroads. Before the Supreme Court, the black workers argued successfully that the Railway Labor Act's grant of exclusive representation to the bargaining agent selected by a majority of workers prohibited that agent from discriminating against a minority. ${ }^{171}$

Second, and most vigorously, the Inc. Fund helped to bring suits in similar cases involving union discrimination against shipyard workers in California, Oregon, and Rhode Island. African American work-

${ }^{169}$ Procedure for Legal Defense and Voting Cases, supra note 13.

${ }^{170}$ See generally ERIC ARNESEN, BROTHERHOODS OF COLOR: BLACK RAILROAD WORKERS AND THE STRUGGLE FOR EQUALITY 138-39 (2001) (examining the black railroad workers' fight against discrimination by the unions, and the NAACP's eventual assistance in that struggle).

${ }^{171}$ Tunstall v. Bhd. of Locomotive Firemen \& Enginemen, 323 U.S. 210 (1944); Steele v. Louisville \& Nashville R.R., 323 U.S. 192 (1944). 
ers complained that their race was the only thing standing between them and union membership and employment in the shipyards. ${ }^{172}$ Because the boilermakers' union had obtained closed shop agreements with many shipyards during World War II-agreements that the company would hire only workers who were members of the unionblack workers found themselves faced with a choice of joining segregated auxiliary locals that deprived them of virtually all the rights of union membership or being fired from their jobs. ${ }^{173}$ As the brief for the black boilermakers put it, "The only matter in which there is entire equality, without discrimination as between Negro and white members is with reference to dues: the dues are equal."174 The Inc. Fund and the private lawyers with whom it worked succeeded in obtaining several state court decisions that required unions either to grant the black workers equal rights within the union or allow them to work without union membership, ${ }^{175}$ though it eventually pursued legal prohibitions on segregation itself in education rather than employment cases. ${ }^{176}$

Finally, the Inc. Fund supported New York's pioneering law against private discrimination in employment in two ways. First, it filed amicus briefs in Railway Mail Ass'n $v$. Corsi, in which the United States Supreme Court upheld the constitutionality of the New York law as it applied to union discrimination. ${ }^{177}$ Second, it brought administrative complaints of employer and union discrimination before the

${ }^{172}$ Draft Brief (n.d.) (on file with NAACP Papers, Part 13, Series C, Reel 2).

${ }^{173}$ The business agent for the auxiliary was appointed by a supervising white lodge and had authority to assign men to jobs; the shop committee set up for handling grievances was appointed and controlled by the supervising white lodge; any upgrading of black workers had to be approved by the white lodge; the auxiliary had no voice or vote in the international conventions; and the auxiliaries and their members, but not white lodges or their members, could be suspended arbitrarily by the international. Press Release, NAACP, NAACP Aids Coast Shipyard Workers (Dec. 3, 1943) (on file with NAACP Papers, Part 13, Series C, Reel 2).

${ }^{174}$ Draft Brief, supra note 172.

175 See, e.g., Williams v. Int'l Bhd. of Boilermakers, 165 P.2d 903, 905 (Cal. 1946) (finding the union's actions were "directed ... against other workers solely on the basis of race and color" and were therefore illegal); James v. Marinship Corp., 155 P.2d 329,342 (Cal. 1944) (upholding an injunction intended to "eliminate discrimination on the basis of race and color alone").

${ }^{176}$ See TUSHNET, supra note 7, at 116 ("Attacking the separate but equal doctrine of Plessy $v$. Ferguson in education was probably the center of the NAACP's efforts."); MARK V. TUSHNET, THE NAACP'S LEGAL STRATEgy Against SEgREgated Education, 1925-1950, at 34 (1987) (quoting Charles Hamilton Houston as saying, "[e]conomically inferior education makes [Negroes] less able to stand competition with whites for jobs" (alterations in original)).

${ }^{177} 326$ U.S. 88, 93-96 (1945). 
New York State Committee Against Discrimination (SCAD). ${ }^{178}$ Though the complaints concerned tunnel workers and railroad workers, postal workers and others, and the challenges ranged from discrimination in hiring to differences in pay to separate facilities on the job, each was similar in the univalence of race.

All of these cases-the railroad cases, the boilermakers cases, and the SCAD complaints-concerned workers who, because they were black, were denied privileges extended to white workers in the same unions, the same jobs, the same companies, the same industries. In each instance, African American workers were treated differently from, and notably worse than, white workers solely because of their race. $^{179}$

In contrast, the problems facing African American agricultural workers in the South were intimately bound up with both their race and class position. These workers were vulnerable because they were poor, isolated, and without the political rights of the white majority. They lived in a world of white economic domination and black economic dependence, of white political power and black disfranchisement, of the ubiquitous potential for legally unrestrained white violence and the almost certain swift retribution against black violence, real or imagined. The combination of racial, economic, and political oppression made black agricultural workers in the South vulnerable to structural exploitation. ${ }^{180}$

In part, the complaints of these African American agricultural workers seem somewhat surprising and anachronistic in the 1940s. By that time, black southerners were more mobile, as evidenced by the fact that approximately two million moved to cities across the country during the decade. ${ }^{181}$ They were entering the military, the war industries, and the urban employment market in large numbers. But it is a Reel 4).

${ }^{178}$ E.g., Monthly Reports, 1946-1947 (on file with NAACP Papers, Part 18, Series A,

${ }^{179}$ Indeed, these workers suffered economic problems too. The basis for their complaints was often the economic disadvantage that accompanied race discrimination and exclusion. But their complaints were treated as solely race based and the problems they faced were generally redressable through race-specific measures.

${ }^{180}$ See generally DANIEL, THE SHADOW OF SlaVERY, supra note 17, at 21 ("The seeds of peonage grew well in social and economic soil so fecund with opression."); MYRDAL, supra note 35, at 77-78 (noting that there was no such thing as a "primary cause" for the plight of black workers); ZANGRANDO, supra note 45, at 12 (coupling the decline in lynching with the rise of alternative political, social, and economic methods of maintaining white supremacy).

${ }_{18}$ Homer C. Hawkins, Trends in Black Migration from 1863 to 1960, 34 PHYLON 140, 148 (1973). 
mistake for historians to follow the fortunes of only those who managed to leave. At the end of the 1940s, twenty-nine percent of African Americans still worked in southern agriculture. ${ }^{182}$

Moreover, it is a mistake to equate regional differences with the elimination or relaxation of the same racialized political economy that had its roots in slavery. Mobility out of the South and mobility within it could not be equated. In fact, the former led to even greater restrictions on the latter. In a time of perceived shortage of agricultural labor-due to the war and migration to cities and the North-landowners resorted to varied methods of coercion and force to maintain a cheap and captive labor force. One might think that a tighter labor market would redound to the benefit of workers, who could, in a free market, command higher wages. But southern agriculture, particularly for African Americans, bore only partial resemblance to a free market. Landowners, with the help of local, state, and federal governments, resorted to extramarket mechanisms, from "work or fight" programs to fabricated debts and charges, from outright force to degrading living and working conditions, from governmentadministered wage ceilings to appropriation of property that kept laborers from obtaining or exercising financial or geographical independence. ${ }^{183}$

Observers often made the race/class connection explicit. Frank Welch, for example, in his land tenure study, stated unequivocally, "[It] cannot be too strongly emphasized that the plantation tenancy system has racial and political as well as economic implications. It is the partially accepted solution to a race problem that has existed since the Civil War." 184 One undated cartoon from the 1940s showed an African American farmer plowing a field with a mule, as a whip held by a white hand is about to strike his back. The heading read, "Slavery in the United States, Peonage," and at the bottom of the picture were

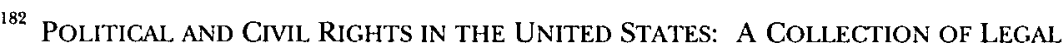
AND RELATED MATERIAL 1142 (Thomas I. Emerson \& David Haber eds., 1952) (citing Margaret Kane, The Nonwhite Housing Market, in InSUREd MORTGAGE PORTFOlio, FOURTH QUARTER 1951, at 23-24 (1952)). See generally BRUCE J. SCHULMAN, FROM CotTon Belt to Sunbelt: Federal Policy, ECONOMIC DEvelopment, AND THE TRANSFORMATION OF THE SOUTH, 1938-1980, at 102-03 (1991) (discussing the causes and consequences of the agricultural labor shortage in the South).

${ }^{183}$ See supra text accompanying notes $140-41$ (providing examples of such extramarket mechanisms).

${ }^{184}$ WEL_CH, supra note 16 , at 54. 
the words "Racial Economic Bondage."

Nor were the race/class connections central to these problems lost on some of those who encouraged the NAACP to act on behalf of southern agricultural workers. Alfred Baker Lewis asserted that the wage ceiling "situation is a rotten one from every point of view both racial and economic." He repeatedly emphasized "that this is the sort of case on economic, legal, and racial grounds we ought to support in every way we can."187 He explained the importance of such cases when he stated, "those who suffer from the imposition of wage ceilings are on the lowest rung of our economic ladder and are also among those most completely denied political, economic, or social rights of all of our citizens."

William Henry Huff, an African American lawyer and selfdescribed crusader against peonage, depicted the race/class interplay in peonage in similar, if more contentious and less analytical, terms. He stated that people in peonage

are under the bottom rail. They are, indeed, defenseless; no one wishes to bother with them because, first, they have absolutely no money, and second, they are at best a debased, ignorant and servile crew. But if we sit idly by and allow the overlords to enslave all who are of their type, ere long the same bell will toll for us in some manner. ${ }^{189}$

He told the NAACP that he was on board with "equal pay for teachers" and "all the other necessary reforms." But he insisted that none should come "at the expense [of] liberty for the peons, the people farthest down." 191 He saw the antipeonage crusade not as separate from or contrasted to other kinds of racial injustice but rather as "'a companion fight to the nation-wide struggle to pass the anti-Poll-tax and anti-Lynching bills and the fight of John L. Lewis to lead the way to-

${ }^{185}$ Clipping (Schomburg Center for Research in Black Culture, New York, New York, Clipping File, 1925-1974, FSN 003, 902-2, Frame 81).

${ }_{186}$ October Letter from Lewis to White, supra note 86.

${ }_{187}$ November Letter from Lewis to White, supra note 124.

${ }^{188}$ Letter from Alfred Baker Lewis to Marian Wynn Perry (Jan. 15, 1946) (on file with NAACP Papers, Part 13, Series C, Reel 2).

${ }^{189}$ Letter from William Henry Huff to Walter White (Nov. 24, 1941) (on file with NAACP Papers, Part 13, Series C, Reel 12).

${ }^{190}$ Letter from William Henry Huff, Chief Counsel, Abolish Peonage Committee of America, to Thurgood Marshall (Dec. 21, 1941) (on file with NAACP Papers, Part 13, Series C, Reel 12).

Id $I$. 
ward smashing the wage-differential." "'92 For Lewis and Huff, the very interconnectedness of race and class made the agricultural cases urgent and significant.

The way in which most farmworker complaints wrapped together multiple levels of oppression and multiple levels of rights demands lent itself uncomfortably, if at all, to a framework of discrimination on the basis of race alone. The Inc. Fund nonetheless sometimes tried to transform the farmworkers' claims-based as they were at least in part on race discrimination-into univalent claims of race discrimination cognizable under its general framework. In response to one complaint letter in which the Association understood the complainant and his wife to be "held on some white person's farm against [their] will," one NAACP lawyer replied: "We are sure that if you are suffering an injustice because of your race the branch will do whatever is possible to help you." $" 193$

The Inc. Fund also suggested redressing peonage through means more commensurate with its other legal activities and interests. The organization received one complaint about a "young Negro child whom it is alleged has been 'sold' to a white woman" in Florida. ${ }^{194}$ After discussing the case with the Department of Justice and concluding that there was no violation of the peonage statute proper (during a time prior to the Department's more expansive use of the civil rights statutes for Thirteenth Amendment protection), ${ }^{195}$ Thurgood Marshall suggested the branch officer take the matter up with the Florida authorities. Marshall was not convinced that any good would come of such a complaint because Florida was so "uncivilized." In concluding his letter to the branch, Marshall took the opportunity to shift the ground to terrain on which he was more comfortable:

This is merely one more [in] a long line of cases which justify our continued action to secure the right to vote for Negroes in Southern states, in order to compel the law-enforcement authorities in these states to give Negroes the equal protection of the laws to which they are entitled. ${ }^{196}$

${ }^{192}$ Press Release, Abolish Peonage Committee of the International Labor Defense, Abolish Peonage Committee Hails U.S. Indictment of Georgia Peonage Land-Lord (n.d.) (on file with NAACP Papers, Part 13, Series C, Reel 12) (quoting Huff).

${ }_{193}$ Letter from Reeves, supra note 155 (emphasis added).

${ }^{194}$ Letter from Thurgood Marshall to James Hoy (Oct. 27, 1941) (on file with NAACP Papers, Part 13, Series C, Reel 12) [hereinafter Letter from Marshall to Hoy].

${ }^{195}$ See Goluboff, supra note 5, at 1654-68 (describing the Department of Justice Civil Rights Section's "broadening" efforts in involuntary servitude prosecutions).

196 Letter from Marshall to Hoy, supra note 194. 
Marshall thereby transformed a peonage complaint into an occasion for promoting voting rights.

Similarly, when Marian Wynn Perry became involved with migrant farm workers in New York state in the late-1940s, the problem as she saw it was not the deplorable conditions in which the migrants all lived, but the fact that the African Americans were in segregated camps whose conditions she thought were worse than the others. ${ }^{197}$ In addition, when H.L. Mitchell of the National Farm Labor Union wrote the NAACP asking the staff "to help protect the rights" of "Negro and white farm workers" who were violently attacked while on strike, ${ }^{198}$ Perry wrote back that "there would certainly appear to be some grounds for intervention by the N.A.A.C.P. to protect these Negro farm workers from violence and police brutality." Perry thus racially divided an interracial strike in order to take interest in African Americans alone.

These transformations of the multivalent race/class complaints of agricultural workers into what the Inc. Fund considered race claims were both haphazard and unsystematic. The reality was that the farmworkers' claims could not be so reduced. The harms they faced were not only many, they were connected and reinforcing. As a result, it was unlikely that a litigation strategy whose sole goal was to wipe out univalent race discrimination and segregation would get the farmworkers very far. Were they legally allowed to vote, they still would have faced intimidation at the polls leveraged by economically powerful landlords. Were they legally able to attend white graduate schools, they likely lacked the means to do so, borrowing as they often were for seeds for the next season's planting. The same held true for the integrated neighborhoods of black and white homeowners that might arise with the unenforceability of racially restrictive covenants. ${ }^{200}$ The

\footnotetext{
${ }^{107}$ Report of the Legal Department for the Month of July 1946 (on file with NAACP Papers, Part 18, Series A, Reel 4).

198 Letter from H.L. Mitchell, President, National Farm Labor Union, to Walter White (July 3, 1946) (on file with NAACP Papers, Part 13, Series C, Reel 2).

199 Letter from Marian Wynn Perry to H.L. Mitchell (July 10, 1946) (on file with NAACP Papers, Part 13, Series C, Reel 2).

${ }^{200}$ During the 1940s, the NAACP focused on litigation challenging white primaries, segregated graduate schools, and racially restrictive residential covenants. See TusHNET, supra note 7, at 81-125 (describing in detail the underlying theories and mechanisms of the NAACP's litigation strategy in the 1940s); MARK V. TUSHNET, THE NAACP's Legal StRategy AGainst SEgREGated EduCATION, 1925-1950 (1987); Clement E. Vose, Caucasians Only: The Supreme Court, the NAACP, and the Restrictive COVENANT CASES 50-74 (1959) (outlining the NAACP's evolving litigation strategy).
} 
integration of unions or employers would have provided little help in the agricultural South. The only union around, the STFU, was already integrated; the workers' problems lay rather in the seemingly overwhelming difficulties the union faced in challenging the political and economic power of the planters. Even if their employers treated them the same as white tenants, sharecroppers, or wage hands with regard to the terms of employment, vast improvements were unlikely. The employer who was also landlord and banker had ways other than racially differentiated wage structures for maintaining dominance.

Thus, not only were the kinds of claims the farmworkers raised repudiated by the Inc. Fund, but the kinds of claims that did fit the Inc. Fund's agenda offered only partial solutions to the farmworkers and their interconnected problems. The Inc. Fund aimed to eliminate racial barriers, not to tackle the combined race and class concerns that arose in the agricultural South. For these workers, racial barriers were only one part of a multifaceted problem. One worker seeking help from the NAACP articulated it this way:

The negroes here most of them is afreaid of the white people here and all of them is afreaid to go to the court house to vote, now take thing's to a consideration, we live's in a free house such as it is, but you can't live in the free house with nothing to eat one half of the time and no shoes and cloth to wear in the winter.

\section{CONCLUSION}

This Article has shown how excavating the race/class complaints that African American agricultural workers presented to the NAACP in the 1940 s changes the historiographical landscape of modern civil rights. First, the farmworkers' multivalent race/class claims disrupt the temporal and conceptual dichotomies that characterize the historiography. The 1940s might have marked more of a shift from class to race for southern agricultural workers if they managed to leave the agricultural South. ${ }^{202}$ Those who stayed continued to live in an environment structured by interconnected racial and economic domination most amenable to challenge by multivalent rights claims. By including agricultural workers in our understanding of rights claimants,

${ }^{201}$ Letter from Robert Hammond, Recording Secretary, Wando, S.C., to NAACP (Apr. 26, 1947) (on file with NAACP Papers, Part 13, Series C, Reel 2).

${ }^{202}$ As I argue elsewhere, the 1940 s represented the apex of public concern for race and labor issues together, not a shift from one to the other, even for African Americans outside the agricultural South. Goluboff, supra note 12. 
we see that the coexistence of race and class marked the rights claims of at least some African Americans during the 1940s.

Second, the disappearance of these claims shows us the openness of civil rights at the time. The Inc. Fund's attack on Plessy was the result of literally hundreds, if not thousands, of cumulative decisions about how to shape a civil rights litigation strategy in the 1940s. Some of those decisions, like the 1950 resolution to attack segregation head on, are well known. ${ }^{203}$ But many others remain obscured. Before legal strategies take such definitive shape, lawyers make choices to pursue some cases and not others. The process begins with the claims individuals assert. It continues with those claims lawyers choose to recognize. And it crystallizes with how lawyers manipulate, translate, and transform those claims through the legal process. Within this dynamic, each complaint the NAACP received was potentially the beginning of a legal proposition or strategy. The Inc. Fund's decisions not to pursue the many cases from the agricultural South constituted doctrinal, political, and institutional choices of the most basic and fundamental kind.

Similar crucial but thus far unexplored choices-particularly to take specific labor and employment cases and, ultimately, not to pursue labor cases at all-continued to mark the Inc. Fund's litigation strategy in the 1940s. ${ }^{204}$ Thus, seeing the Inc. Fund's choice to reject the race/class claims of agricultural workers as a choice is only the beginning of a process of reshaping the historiography. So long as historians continue to identify a simple and binary "shift" from class regulation to race-based rights during that decade, they remain captive to the Inc. Fund's success in transforming exclusively race-based discrimination claims into legally recognized rights while leaving multivalent claims hidden in the NAACP's archives. Refusing to take the prominence of univalent claims and the obscurity of multivalent claims for granted is the first step toward a new historiographical freedom and a better understanding of the significance of class in the creation of modern civil rights.

${ }^{203}$ See, e.g., TUSHNET, supra note 176, at 136-37 (noting the adoption of the 1950 resolution).

${ }^{204}$ See Goluboff, supra note 12 (exploring the Inc. Fund's decisions not to pursue employment and union discrimination cases in the 1940s). 